Article

\title{
Corporate Social Responsibility Disclosure and Performance: A Meta-Analytic Approach
}

\author{
Dolores Gallardo-Vázquez ${ }^{1, * \mathbb{C}}$, María J. Barroso-Méndez ${ }^{2} \mathbb{E}$, María L. Pajuelo-Moreno ${ }^{3}$ \\ and Julio Sánchez-Meca ${ }^{4}$ (D) \\ 1 Department of Financial Economics and Accounting, Faculty of Economics and Business, \\ University of Extremadura, 06006 Badajoz, Spain \\ 2 Department of Business Management and Sociology, School of Industrial Engineering, \\ University of Extremadura, 06006 Badajoz, Spain; mjbarroso@unex.es \\ 3 United Arab Emirates University Sheik Khalifa Bin Zayed Street, Al Ain-Abu Dhabi, UAE; \\ mlpajuelo@gmail.com \\ 4 Department of Basic Psychology \& Methodology, Faculty of Psychology, University of Murcia, \\ 30100 Murcia, Spain; jsmeca@um.es \\ * Correspondence: dgallard@unex.es; Tel.: +34-924-289520 (ext. 89163)
}

Received: 20 January 2019; Accepted: 14 February 2019; Published: 20 February 2019

\begin{abstract}
Currently, a lack of consensus exists in the literature on the link between performance and corporate social responsibility disclosure (CSRD). A meta-analysis was carried out to shed light on this controversial topic, using the ABI/Inform Complete and EconLit databases as search tools. To isolate articles with substantive, methodological relevance, various filters were used. In addition to other criteria, all articles had to contain certain keywords related to the study's variables and at least one of the seven keywords indicating empirical data analysis. As a result of this procedure, the meta-analysis included only 95 articles. To process the sample, we employed the procedure developed by Hunter and Schmidt. The results show that the CSRD-performance relationship is not significant enough for practical purposes. However, an analysis of moderating variables revealed that the connection becomes of practical importance when moderated by three key variables: region, type of disclosure, and measures of organization size. This research's findings make a significant contribution by clarifying the links between CSRD and performance and identifying which variables can explain the diverse results of previous research. Regarding limitations, the meta-analysis was subject to the availability of published research and included only studies that reported Pearson correlation coefficients and standardized beta coefficients.
\end{abstract}

Keywords: corporate social responsibility; information disclosure; performance; meta-analysis; empirical study

\section{Introduction}

This study focused on two topics that are currently important to organizations: the disclosure of corporate social responsibility (CSR) information about companies' initiatives and these firms' performance. Various aspects of CSR disclosure (CSRD) have, in recent years, come together to shape a new way of doing business (i.e., internally and externally) and to create a new paradigm of sustainability. The literature mentions many reasons why companies voluntarily disclose information. These motivations range from satisfying stakeholders' needs (i.e., stakeholder theory) that have the most influence on organizations' survival [1-8] to seeking to legitimize company activities (i.e., legitimacy theory) [9-13]. Other reasons are organizations' social responsibility [14], their desire to improve their reputation (i.e., risk management) [15-19], relevant cultural differences, 
and institutional pressures (i.e., institutional sociology) [20-24]. A final motivation can be the redistribution of organizations' wealth and power throughout society (i.e., theory of political economy) [25]. Also, the influence of pro-environmental disclosure and the mediating role of the environmental organizational structure have been strongly questioned [26].

With the empirical verification of unusual patterns of climate change, a series of international agreements have sought to foster worldwide initiatives to protect the environment and prevent global problems connected to climate change. In 2015, the Paris Agreement was ratified by 96 individual signatory countries and the European Union (EU). Following up on the Kyoto Protocol, the agreement's stated objective is to maintain "the increase of the global average temperature below $2{ }^{\circ} \mathrm{C}$ and continu[e] ... efforts so that it does not exceed $1.5^{\circ} \mathrm{C}$ with respect to pre-industrial temperatures." This goal can be said to imply the need to measure organizational performance's net contribution to sustainability.

The necessity of assessing organizations' environmental sustainability practices has combined with the increasingly forceful demands made by much of society that companies be held responsible for their unethical practices $[27,28]$ and recognized for their socially responsible actions. These trends have led to widespread questioning of the political, economic, and ethical basis of contemporary societies, resulting in a call to arms regarding environmental and social protection. Organizations are expected to operate within the value systems dictated by the societies in which they function [29]. These pressures have empowered all members of society to require transparency for all stakeholders and society in general [30], including the disclosure of information that can be useful to stakeholders' decision-making processes [31-33].

In addition, numerous authors have highlighted the importance of organizations achieving high enough performance to ensure their long-term survival on both an economic and environmental level [34,35]. Many researchers have thus sought to conceptualize organizational performance and analyze its different dimensions or measures, as well as examining its relationships with other variables of relevance to organizations.

As a result of CSRD's growing importance, various authors have recently focused on the link between information disclosure and organizational performance in order to understand the connection between these issues. However, previous studies' findings are unclear about the relationship's sign or magnitude. This lack of consensus in the literature has generated an intense, long-lasting debate about the widespread discrepancies in the empirical results obtained, which makes a meta-analysis an appropriate method to use to shed light on inconsistencies in the existing research.

Therefore, the present study's main objective was to carry out a meta-analysis to determine whether a relationship exists between CSRD and organizational performance. If this connection was confirmed, the research would include finding out whether the link is positive or negative, as well as measuring its magnitude. The meta-analysis' specific objectives were to:

1. Provide a statistical data integration of previous research on the relationship between CSRD and organizational performance;

2. Examine different variables that can moderate this relationship: organizational performance, type of disclosure, activity sector, region, type of organization, and measures of organization size.

The analysis of moderating variables was carried out by dividing the sample of primary studies into different subgroups according to the variable under study. First, to analyze the type of performance's influence, the relevant primary studies were divided into two subgroups of research: studies that focused on analyzing organizations' financial performance and research that concentrated on environmental performance. Second, with regard to the type of information disclosed, the primary studies were divided into three subgroups: research focused on analyses of social information, studies that examined environmental information, and works that concentrated on economic information. Third, to analyze the sector of activity's effect, the relevant studies were organized according to the sector of activity analyzed, which created two subgroups: those examining environmentally sensitive sectors and those analyzing environmentally non-sensitive sectors. 
Fourth, in relation to type of organization, the studies in question were divided into three subgroups: works analyzing private organizations, studies focusing on public organizations, and research examining mixed organizations (i.e., private and public). Fifth, to analyze the surrounding region's influence, the primary studies were categorized according to the type of region under study, thereby creating four subgroups. These were works focused on American organizations, studies based on a sample of organizations in Asia, research that concentrated on analyzing European organizations, and studies focused on samples of organizations in Oceania. Last, in relation to measures of organizations' size, the relevant studies were divided according to the measures used to assess company size. Seven subgroups were found: log of total assets, total assets, log of total sales, total sales, log of market capitalization, market capitalization, and log of revenues.

Additional variables that influence the relationship under study would have been interesting to analyze, including, among others, corporate governance variables. According to Shleifer and Vishny [36], corporate governance can be understood as the set of mechanisms that align the providers of finance and company managers' objectives and interests so that the former can enjoy a degree of certainty that balances off the risk of making their funds available to managers. This also can help financers avoid having to deal with company managers' opportunistic behaviors.

Numerous mechanisms of corporate governance have been identified. In Gompers, Ishii, and Metrick [37] and Giroud and Mueller's [38] work, governance is measured using the g-index, which consists of 24 antitakeover and shareholder rights provisions. These include anti green mail, blank check preferred stock, business combination laws, bylaw and charter amendment limitations, classified boards, compensation plans with changes in control provisions, director indemnification contracts, control share cash-outs, cumulative voting, and directors' duties. Other mechanisms are fair-price requirements, golden parachutes, director indemnification, limitations on directors' liability, pension parachutes, poison pills, secret ballots, executive severance agreements, silver parachutes, and special meeting requirements. Still other provisions included in the g-index are supermajority requirements for approvals of mergers, unequal voting rights, and limitations on actions by written consent.

Other authors have classified the mechanisms of corporate governance in two groups [39,40]: internal mechanisms (set up by the company itself) and external mechanisms (linked to the different markets in which the company maybe present). The internal mechanisms include, on the one hand, ownership structure (degree of concentration and large shareholder identity) and, on the other, the board of directors and its functioning in association with certain characteristics: board independence [41-46], board size [45,47,48], percentage of women on board [42,49], and CEO (chief executive officer) duality [43,48,50], among others; And the external mechanisms include market for corporate control and institutional and regulatory environments.

However, these moderator variables were not included in the present meta-analysis because all the primary studies would have had to provide results on the subgroup correlations between CSRD and performance, but these data were not available for the two variables under study.

This research's findings, nonetheless, contribute to the literature in various significant ways. First, as the meta-analysis was based on a comprehensive search of the existing literature, this study is the first to focus on the empirical evidence for the relationship between CSRD and organizational performance. Prior meta-analyses have focused on studying the relationship between social performance and financial performance [51-53] or CSR and performance [54]. Moreover, the current meta-analytical study was based on a large sample of studies (i.e., 95), thereby allowing an appropriate estimation of the population value for the relationship under study.

Second, this research's approach contributes to the literature as the methodology included examining different variables that can moderate the CSRD-performance relationship. Following Dang et al.'s [55] recent recommendations, we incorporated a moderating variable not included in any previous meta-analytical study - measures of organization size-which proved to be an important variable that helps explain the results of previous research. Given the effect sizes obtained in the 
current meta-analysis, the most appropriate measure of organizations' size in this area of research is "total assets" since this ensures a higher effect size in relation to the other measures studied.

Last, this investigation's findings have important theoretical and practical implications. By summarizing research results across a large number of studies and uncovering a significant number of moderators, this meta-analysis revealed how sampling techniques, study designs, and construct measurements can influence research findings. Moreover, the present study's results provide solid evidence of the increasingly prominent role that the CSRD-performance relationship has in the literature, as well as highlighting new questions for researchers about this link's temporal and contextual boundary conditions.

Regarding practical implications, organizations can draw on the current findings when deciding what type of information to disclose. The meta-analysis's results underline the importance of disclosing social information, which could change managers' overall vision and encourage them to pay more attention to the disclosure of this information. Moreover, organizations could benefit from the finding that they should pay more attention in CSR information disclosure when they conduct business activities in certain regions. More specifically, in three regions-the Americas, Asia, and Oceania-the relationship under study can be considered significant for practical purposes. These results could be quite important for managers of different organizations because, given regional cultures' influence on the CSRD-performance relationship, managers need to develop specific strategies to deal with these variations. Therefore, the managers of organizations claiming to be innovative and to use a strategic approach to CSR information disclosure can also benefit from developing innovative internal practices and external initiatives that could potentially transform entire industries.

To clarify how this study achieved results that include these contributions and implications, the paper below is organized as follows. Section 2 reviews the relevant literature published from 1980 to 2018 on the association between organizations' performance and information disclosure, and presents the moderators of the relationship between CSRD and performance. Section 3 offers details on the methods and data collected, while Section 4 provides a discussion of the meta-analysis's main results. Section 5 includes the study's conclusions and limitations, as well as suggestions for future lines of research.

\section{Literature Review and Hypotheses}

\subsection{Debate about Relationship between Corporate Social Responsibility Disclosure (CSRD) and Performance}

This study focused on two main research questions in two successive steps. The first question was addressed in Step 1: Does a relationship exist between CSRD and performance, and, if so, what type of relationship is it? The objective was to address various related questions:

- Has evidence of any relationship between CSRD and performance been found?

- What sign does the link present: positive or negative?

By answering these questions, we sought to confirm and elucidate the relationship between the variables under study.

The second step addressed another central research question in Step 2: what variables, if any, modify this relationship? Based on the results obtained in the first step, the next step sought to confirm if any variables moderate the relationship. To clarify these objectives, we proposed eight hypotheses, as described in the next two subsections.

\subsection{Positive, Negative, and No Relationships between Variables Under Study}

Numerous studies' results have shown different findings in relation to the link between CSRD and performance, including a positive, neutral, or negative relationship. Patten [56] argues that the existing literature on CSRD has generated controversy for different reasons such as small samples or limited performance measures. The following discussion seeks to summarize the research reported in the literature that supports these three possible results. 


\subsubsection{Positive Relationship}

Many researchers have found evidence for a positive relationship between CSRD and performance. According to these studies, higher performance levels can foster greater CSRD when company directors seek to send out signals of their competency to investors. Orlitzky et al. [51] also suggest that voluntary disclosure activities promote better corporate performance-specifically stronger financial performance- thereby favoring firms' investment in CSRD activities.

Al-Tuwaijri et al. [57] mention that voluntary disclosure scores are higher for businesses with better environmental performance. In Amran's [58] opinion, firms that generate more profits can afford to engage more actively in CSRD. Other authors $[59,60]$ assert that listed businesses with stronger performance disclose more information than other companies do and engage in more social sustainability activities. These firms then disclose information about these initiatives to reduce the risks associated with corporate activities that have negative social and environmental impacts.

In addition, Clarkson et al. [61] found a positive link between environmental performance and social and environmental disclosure in reports and/or online disclosure. Artiach et al. [59] also argue that more profitable firms are more likely to have the resources needed to engage in activities related to sustainable development, so reporting these are more important for higher profile companies. Cho et al. [16] validated, on one hand, a positive link between CSRD and environmental reputation measures and, on the other hand, a positive relationship between CSRD and membership in the Dow Jones Sustainability Index (DJSI).

Clarkson et al. [62] demonstrated that voluntary environmental reporting provides useful information to those seeking to forecast companies' financial performance. The cited authors' findings further show that a proactive environmental strategy can improve companies' stock prices. These results can help CSR practitioners convince company managers that proactive strategies combined with transparent disclosure are extremely valuable.

Businesses attempting to improve their legitimacy tend to utilize communication strategies such as financial reporting in order to influence society's perceptions. Because corporate environmental reporting remains largely a voluntary action, companies' managers can use disclosure as a legitimating device [63]. In addition, legitimacy theory suggests that greater visibility leads to stronger pressures from society [64]. This theory further predicts that businesses with higher profits will provide more greenhouse gas information, so society expects more successful businesses be more responsible in terms of reducing their greenhouse gas emissions [65]. Simultaneously, businesses with worse environmental performance experience greater social and political pressures, so these companies tend to disclose more information in order to reduce their exposure [63,66,67]. Finally, Mallin et al. [68] highlight a positive association between their CSRD index and banks' financial performance.

\subsubsection{Negative Relationship}

However, many authors have reported finding proof of a negative relationship between CSRD and performance $[16,69,70]$. Some researchers have found that low performance can lead to greater disclosure in various circumstances. These include avoidance of reputational costs [70] and cases of shareholder litigation [71]. Leuz [69] suggests a negative link exists between companies' level of voluntary disclosure and profitability. More recently, Cho et al. [16] observed that environmental performance has a negative relationship with environmental voluntary disclosure.

\subsubsection{No Relationship}

Other authors have argued that no relationship exists between the variables in question. Freedman and Jaggi [72] suggest that no evidence can be found for an association between profitability and CSRD. Aupperle et al. [73] further report that CSRD activities have neutral effects on profitability. Dumontier and Raffournier [74] and Meek et al.'s [75] results confirm the absence of a link between profitability 
and voluntary information disclosure, while McWilliams and Siegel [76] did not find a relationship between CSRD and financial performance.

In addition, Ball et al. [77] report that companies with poor performance may reveal more information, albeit primarily to disguise weak performance with complex rhetoric and wording in annual reports. Connelly and Limpaphayom [78] did not find a relationship between environmental disclosure and accounting performance, but their results suggest that reporting good environmental practices does not negatively affect short-term profitability. Forte et al. [79] assert that performance is not a factor influencing levels of voluntary reporting by businesses in Brazil's banking sector. Based on an analysis of 195 Spanish companies subject to the Kyoto Protocol, Pajuelo [80] could not discover any empirically robust evidence for a significant relationship between companies' financial capacity-measured through economic profitability, operating profitability, indebtedness, earnings before interest and tax, financial profitability, and assets-and these firms' environmental proactivity, social and environmental information disclosure, and measures of sustainability.

Previous theoretical studies have thus highlighted the difficulty of studying the link between companies' performance and disclosure of socially responsible activities [78]. The existing findings provide contradictory answers to the research questions raised in this section's first paragraphs about the existence of a CSRD-performance relationship, its sign (i.e., positive or negative), and its magnitude. Some researchers have argued that firms with good performance are more likely to provide voluntary disclosure, while other scholars argue that companies with low performance are the most likely to reveal voluntary information. Still other investigators have confirmed that no relationship exists between CSRD and performance. Therefore, a meta-analysis of this field needed to be conducted because, based on the previous literature, no consensus has been reached on the relationship under study. Given the above findings, we proposed the following hypothesis:

Hypothesis 1 (H1). A link exists between CSRD and organizational performance.

\subsection{Moderators of Relationship between CSRD and Performance}

According to Miras-Rodríguez et al. [54], many studies have found it more convenient to introduce certain moderating variables that strengthen the connection between CSRD and performance, thereby facilitating further advancements in this field [81-83]. The present study thus sought to analyze the evidence for various variables' possible moderating effects on this relationship.

The existing literature suggests CSRD can have various dimensions including economic, environmental, and/or social aspects. The current research's objective was to assess these aspects' different possible effects by combining observed dimensions with various performance measures. The first step was to define information dissemination and company performance, which, as mentioned above, can be measured in quite different ways. This disparity in performance measures, led us to propose the following hypothesis:

Hypothesis 2 (H2). The method used to measure performance (i.e., financial or environmental) moderates the relationship between CSRD and organizational performance.

Regarding financial performance and, more specifically, the measures used to assess it, some authors have employed market measures, while other scholars have used accounting measures. Given these distinct approaches, we decided to analyze different variables' effect on the CSRD-performance relationship in order to find out whether the CSRD dimensions used affect the link's results. Some authors have considered global CSRD and profitability [47,60,84-86], while others have studied CSRD and performance [79,87]. Francis et al. [88], more specifically, studied CSRD and financial performance.

The present study included the different measures found in the existing literature. Our first focus was on return on assets (ROA), based on Cho et al. [16], Clarkson et al. [61], Connelly and Limpaphayom [78], Dawkins and Fraas [32], and Francis et al.'s [88] research. In addition, we included 
return on equity (ROE) to reflect Dawkins and Fraas [32] and Forte et al.'s [79] work. Leverage was also considered based on Clarkson et al. [61], Connelly and Limpaphayom [78], Dragomir [89], Gao and Connors [90], and Ho and Wong's [86] papers. Finally, Tobin's q was included because Connelly and Limpaphayom [78], Dragomir [89], and Drobetz et al. [33] used this measure.

Since financial performance can be assessed via accounting or market measures, we proposed that these measures have a moderating effect on the link between CSR-related reporting and financial performance. Market-based measures rely on the idea that shareholders constitute a primary stakeholder group whose satisfaction affects companies' overall goals [91]. Accounting-based indicators, such as ROA and ROE, convey companies' internal efficiency [91]. The present study thus proposed the following hypothesis:

Hypothesis 3 (H3). The method used to measure financial performance (i.e., accounting or market measures) moderates the relationship between CSRD and organizational performance.

Clarkson et al. [62] and Freedman and Jaggi [92] examined the link between environmental voluntary disclosure and financial performance. The cited authors report that a proactive environmental strategy and signals of this tactic sent to stockholders can increase companies' stock prices. Hasseldine et al. [93] also studied environmental disclosure and economic performance, while Cormier and Magnan's [31] results indicate that the ways firms release this information affect the market valuation of their earnings. Therefore, studies need to control for endogeneity between companies' decision to disclose information and their market value.

Cho et al. [16] assessed the links between environmental reporting and environmental and/or financial performance. The cited authors argued that businesses utilize environmental disclosure primarily as a strategic instrument to reduce political and regulatory pressures on these firms rather than as way to attain superior performance. Guidry and Patten [94] also analyzed the relationship between environmental reporting and environmental performance. In this case, the findings show that environmental disclosure mediates the effect of low environmental performance on reputation. Papers published by Dawkins and Fraas [32,95], Delmas and Blass [96], Dragomir [89], Freedman and Jaggi [92], and Gao and Connors [90] report similar findings.

In contrast, Michelon [18] examined the relationship between economic and social disclosure and performance among continental European, United Kingdom (UK), and United States (US) businesses. Drawing on legitimacy theory, the cited researcher suggests that firms' reputations are one reason why firms engage in sustainability reporting. Michelon's [18] study more specifically considered the definition of reputation on three levels: stakeholders' commitment, financial performance, and media exposure. The cited author argues that businesses with a stronger financial performance apply a strategic approach to satisfy interest groups and experience pressures from society, so these firms are more likely to use sustainability reporting to inform stakeholders about their operations' legitimacy. Michelon's [18] results thus reveal a positive relationship between the following variables: interest groups' commitment, media exposure, and sustainability disclosure.

Subsequently, Salem et al. [97] examined the link between CSRD and organizational performance in terms of financial performance, employee commitment, and corporate reputation for a sample of Libyan businesses subjected to stakeholder pressures. The cited study revealed a positive link between CSRD and organizational performance with regard to financial performance and corporate reputation, but no significant relationship was found between CSRD and employee commitment. Thus, the following hypothesis was proposed for the present study:

Hypothesis 4 (H4). The type of disclosure (i.e., economic, social, or environmental) moderates the relationship between CSRD and organizational performance.

Another aspect highlighted in the current research was the possible effect of internal organizational factors on the CSRD-performance relationship. Contrafatto [98] points out that, while some studies 
have focused on the reasons for CSRD [99-101], other researchers have examined the effects of internal organizational factors. The latter have an impact on the nature, quality, and significance of social disclosure $[99,102]$.

Primarily in the last 20 to 25 years, both the private and public sectors have begun to focus on social, environmental, and ethical issues, as well as on CSR and sustainability [103]. Researchers have suggested that larger private businesses are subject to stronger pressures from interest groups and, therefore, that these firms are expected to be more easily persuaded by public opinion in favor of disclosing social and environmental information $[16,89,96,103-106]$. In the public sphere, institutional factors are associated with external forces or pressures exerted by citizens, which are the initial triggers of changes [62,78,107].

Overall, studies' results for the public sector show a lower average correlation between CSRD and performance than research on the private sector. Given this difference, the present study proposed the following hypothesis:

Hypothesis 5 (H5). The type of organization (i.e., private, public, or mixed) moderates the relationship between CSRD and organizational performance.

Sector of activity was another of the internal organizational factors that we decided to analyze in order to elucidate which variables moderate the CSRD-performance link. This variable has been mentioned in the literature as one of the most significant factors when researchers seek to clarify variations in reporting levels. The industry involved has also been shown to be a determinant of environmental information $[108,109]$ and CSR reporting [60,110].

Patten [111] argues that an industry's greater visibility may foster disclosure as businesses tend to avoid unnecessary pressure and criticism from social groups. The cited author utilized size and industry as proxies for pressures from society, based on the assumption that larger businesses and those in environmentally sensitive industries are more exposed to these pressures. Patten's [111] results show a positive correlation for both variables with CSRD. Roberts [112] also demonstrated that high-profile industries are more likely to present higher levels of social responsibility reporting. The cited researcher asserts that high-profile sectors of activity tend to have more environmental and social disclosure. However, Cho et al. [16], Clarkson et al. [61], Clarkson et al. [62], Kansal et al. [106], Luethge and Guohong Han [113], and Magness [114] published papers on companies classified as part of so-called "sensitive" sectors. These studies found a lower average correlation with CSRD than those conducted in "non-sensitive" sectors [48,68,79,104,115].

Based on the existing literature, the present study classified industries into environmentally sensitive or not sensitive, assuming that the former sectors tend to have more environmental and social reporting. Thus, our sixth hypothesis was:

Hypothesis 6 (H6). The sector of activity (i.e., environmentally sensitive or not) moderates the relationship between CSRD and organizational performance.

Another aspect that moderates this relationship is cultural differences between countries. Cultural traditions, legislation, and socioeconomic contexts are, among others, aspects that describe variations among countries, and these aspects influence CSR attitudes and disclosure [110]. Miras-Rodriguez et al. [116] refer to numerous studies revealing important cultural differences in environmental and ethical behaviors. These include contrasts found between the most reputable US companies and European firms [117], between two countries (e.g., Spain and the UK) [118], and between three countries (e.g., Sweden, Canada, and Australia) [119].

The literature suggests that, in general, UK, US, and continental European businesses have been implementing CSR activities for years and that these initiatives are at the core of firms' business strategies. However, most organizations from developing countries have only started to carry out CSR activities in recent years to legitimize their operations. In terms of CSR reporting, numerous 
studies have detected differences among countries. Variations have been confirmed between European, Japanese, and US companies [120]; US and EU firms [121]; Scandinavian and US companies [122]; and US, Japanese, German, French, and UK organizations [123].

After evaluating the entire body of studies carried out in different regions, the present study found that the average total correlation between CSRD and performance is higher in Asia and lower in the Americas, the Middle East, Oceania, Africa, and Europe. Thus, based on the existing literature, we expected that different cultural characteristics and behaviors associated with each country moderate the CSRD-performance relationship. Our seventh hypothesis was formulated as follows:

Hypothesis 7 (H7). The region under study moderates the relationship between CSRD and organizational performance.

Company size is commonly used as an important variable that affects both companies' disclosure of information [124-126] and performance [62,127]. An organization's size is measured by using different measures. For instance, Al-Ajmi et al. [128] used the logarithm of total sales as a measure of company size, as did Bens and Monahan [129]. Other measures utilized have been the natural log of total assets [46,124], market capitalization [130], total assets [1,86,131], and sales [132].

In a recent publication, Dang et al. [55] mentioned the importance of assessing the sensitivity of empirical results in different areas to different measures of organization size. The cited authors confirmed that the correlations between different variables can change sign and significance when different size measures are used. Based on the above findings, the following hypothesis was proposed for the present study:

Hypothesis $\mathbf{8}$ (H8). The measures of organization size used moderate the relationship between CSRD and organizational performance.

\section{Methods and Data}

In recent years, meta-analytic studies have gained greater prominence in the literature as a new methodology that provides literature reviews with the empirical rigor, objectivity, and systematization needed to assess successfully the state of the art of scientific knowledge [133]. Meta-analysis is a particularly valuable tool for summarizing research findings in a quantitative way [134-136]. The value of meta-analysis as a research method is due to two specifically relevant aspects [137]: potentially divergent empirical results can be synthesized while the role of a specific set of variables can be explored at the same time. Therefore, meta-analysis has been established as a crucial methodological tool to integrate quantitatively the results of a large number of primary works $[44,138,139]$. By combining the findings of these studies into a single assessment, meta-analysis enables researchers to check hypotheses that are normally not testable, thereby obtaining more appropriate conclusions [140].

Hawcroft and Milfont [141], Marcus et al. [142], Sánchez-Meca [143], Sánchez-Meca et al. [144], and Wallace et al. [145] established the procedures for meta-analyses. The cited authors all list eight necessary steps: (1) inclusion criteria, (2) literature search, (3) sample of studies, (4) coding procedure, (5) database creation, (6) choice of effect size index, (7) statistical analysis and interpretation, and (8) disclosure of results. In addition, the present meta-analysis followed the Preferred Reporting Items for Systematic Reviews and Meta-Analyses (PRISMA) guidelines [146]. Notably, the PRISMA checklist was developed to be applied in meta-analyses of research on interventions' effectiveness. As the present meta-analysis did not focus on intervention evaluation, some PRISMA items were not deemed applicable. Supplementary File 1 presents the PRISMA checklist used for this meta-analysis. 


\subsection{Study Selection Criteria and Literature Search}

The search process reflected several choices. The first choice established the study selection criteria. To be included in this meta-analysis, the works had to fulfill the following selection criteria: (1) an empirical study with organizations as the analysis unit, (2) research on the link between CSRD and performance, (3) the use of Pearson correlation coefficients-or a similar measure-between the two variables of CSRD and performance, and (4) a publication in English or Spanish.

The second choice was to use both the ABI/Inform Complete and EconLit databases as search tools. These were selected because of their extensive full-text coverage of documents and multidisciplinary nature [147]. Our next step was to separate documents related to the link between CSRD and organizational performance out of the great number of documents compiled in ABI/Inform Complete and EconLit. In order to minimize subjectivity, we followed a systematic, replicable procedure to select works, which had been previously used by David and Han [147] and Newbert [148]: environmental disclosure" OR "social disclosure" OR "economic disclosure" OR "environment

Given that the available search tools allow researchers to look for desired words, we formulated the search criteria based on keywords that are likely to be found in works related to our topic. The first step was to define the search period. Our search included relevant works published up to 30 September 2018 (i.e., the date last searched). Because the oldest study was published in 1982, the studies cover 36 years of research on this relationship. The second step was to isolate works with substantive relevance, namely, those related to research on the CSRD-performance relationship.

To this end, keywords related to "CSR disclosure" AND "performance" were used as search criteria at the same time. These included: "corporate social responsibility disclosure" OR "CSR disclosure" OR "Corporate responsibility disclosure" OR "corporate social disclosure" OR "corporate economic disclosure" OR "corporate al disclosure" OR "sustainability disclosure" OR "nonfinancial disclosure" OR "non-financial disclosure" OR "sustainable disclosure" OR "voluntary disclosure" OR "corporate social responsibility reporting" OR "corporate responsibility reporting" OR "corporate social reporting" OR "CSR reporting" OR "corporate economic reporting" OR "corporate environmental reporting" OR "sustainability reporting" OR "sustainable reporting" OR "nonfinancial reporting" OR "non-financial reporting" OR "social reporting" OR "environmental reporting" OR "economic reporting" OR "voluntary information" OR "voluntary reporting" OR "triple bottom line reporting" AND "performance" OR "financial performance" OR "economic performance" OR "social performance" OR "environmental performance" OR "corporate philanthropy" OR "return on sales" OR "ROS" OR "return on investments" OR "ROI" OR "return on assets" OR "ROA" OR "return on equity" OR "ROE" OR "excess market value" OR "EMV" OR "market returns" OR "return" OR "profit" OR "profitability measure".

These keywords had to appear in any field except the complete text. Some keywords used, for instance, "profit" or "return*," had an asterisk added to them, which indicated that variations on these words' ending were accepted. This produced 1659 results in ABI/Inform Complete and 261 in EconLit. While this helped us to find works with substantive relevance, many of these were not based on empirical research. Thus, we introduced the following seven methodological keywords as filters: "data" OR "empirical" OR "test" OR "statistical" OR "finding*" OR "result" OR "evidence." These keywords had to appear in any field. This produced 1313 results in ABI/Inform Complete and 194 in EconLit. These documents' abstracts, however, revealed that many of the works were still not appropriate because of our research objectives. Some documents made no mention of empirical data, while others were not specifically focused on the variables under study. This additional step reduced the number of documents down to 405 in ABI/Inform Complete and 53 in EconLit.

The final step in our search process was to save and read the remaining documents. This confirmed that the above process had indeed appropriately deleted numerous works, but we also found that many documents were still inappropriate for our meta-analysis. Some were entirely descriptive, while other documents did not have the appropriate empirical data or report any statistical tests' findings. Still other documents did not establish a direct link between the variables selected for the 
present study. This last step reduced the number of works to 86 in ABI/Inform Complete and 24 in EconLit. The databases had 15 works in common, which resulted in a final total of 95 published papers. A summary of the search procedure followed is presented in Table 1, and full references are provided for the final list of documents in Appendix A.

Table 1. Summary of selection process.

\begin{tabular}{|c|c|c|c|c|}
\hline Filter Type $^{1}$ & Description & ABI/Inform Result & EconLit Result & Total \\
\hline Substantive & $\begin{array}{l}\text { All works selected for keywords related to } \\
\text { our key variables }\end{array}$ & 1659 & 261 & 1920 \\
\hline Methodological & $\begin{array}{l}\text { At least } 1 \text { of } 7 \text { keywords required to indicate } \\
\text { empirical data or analysis }\end{array}$ & 1313 & 194 & 1507 \\
\hline $\begin{array}{l}\text { Substantive and } \\
\text { methodological }\end{array}$ & $\begin{array}{l}\text { Remaining abstracts read for both } \\
\text { substantive relevance and statistical analysis }\end{array}$ & 405 & 53 & 458 \\
\hline $\begin{array}{l}\text { Substantive and } \\
\text { methodological }\end{array}$ & $\begin{array}{l}\text { Remaining full works read for both } \\
\text { substantive relevance and statistical analysis }\end{array}$ & 86 & 24 & 110 \\
\hline Duplicated & $\begin{array}{l}\text { Duplicate works found in both } \\
\text { databases deleted }\end{array}$ & & & 95 \\
\hline
\end{tabular}

\subsection{Data Extraction Process}

Table 2 includes a brief reference to the year, sample size, Pearson correlation coefficient for the CSRD-performance relationship, and sector of activity referred to in each article. Based on these 95 papers, we were able to assess a total of 97 estimated effect sizes. Following the procedure used by other meta-analyses [149], when the articles provided more than one estimated effect size for the same link and sample, we used the mean value. When the effect sizes were independent (i.e., from different samples), they were included as separate data. The data from the final document sample were introduced into an Excel spreadsheet. The column headings were (1) author, (2) year, (3) journal, (4) sample size, (5) type of relationship, (6) type of organization, (7) sector of activity, (8) country, (9) region, (10) measures of CSRD, (11) measures of performance, and (12) measures of organization size.

Table 2. Papers considered in meta-analysis.

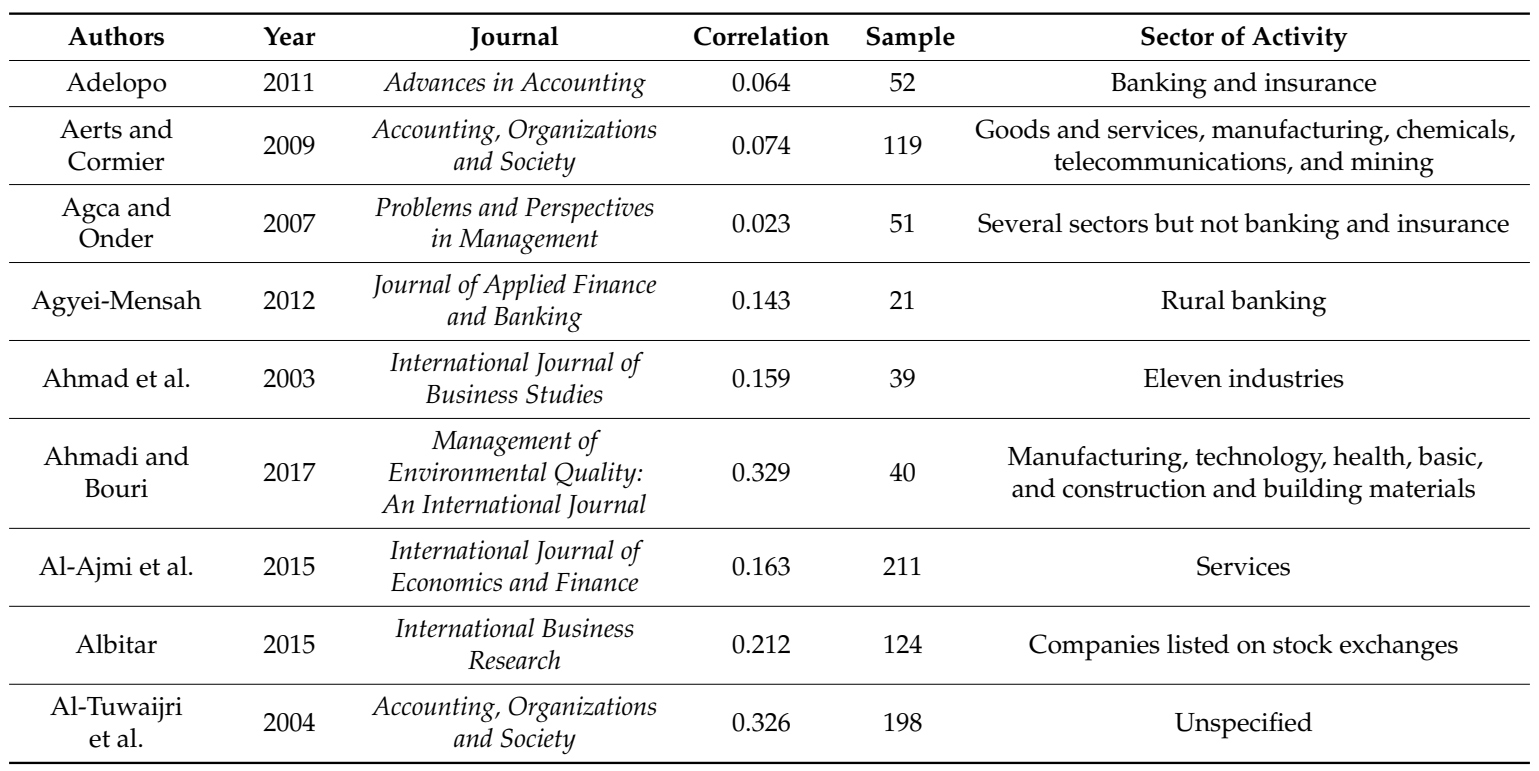


Table 2. Cont

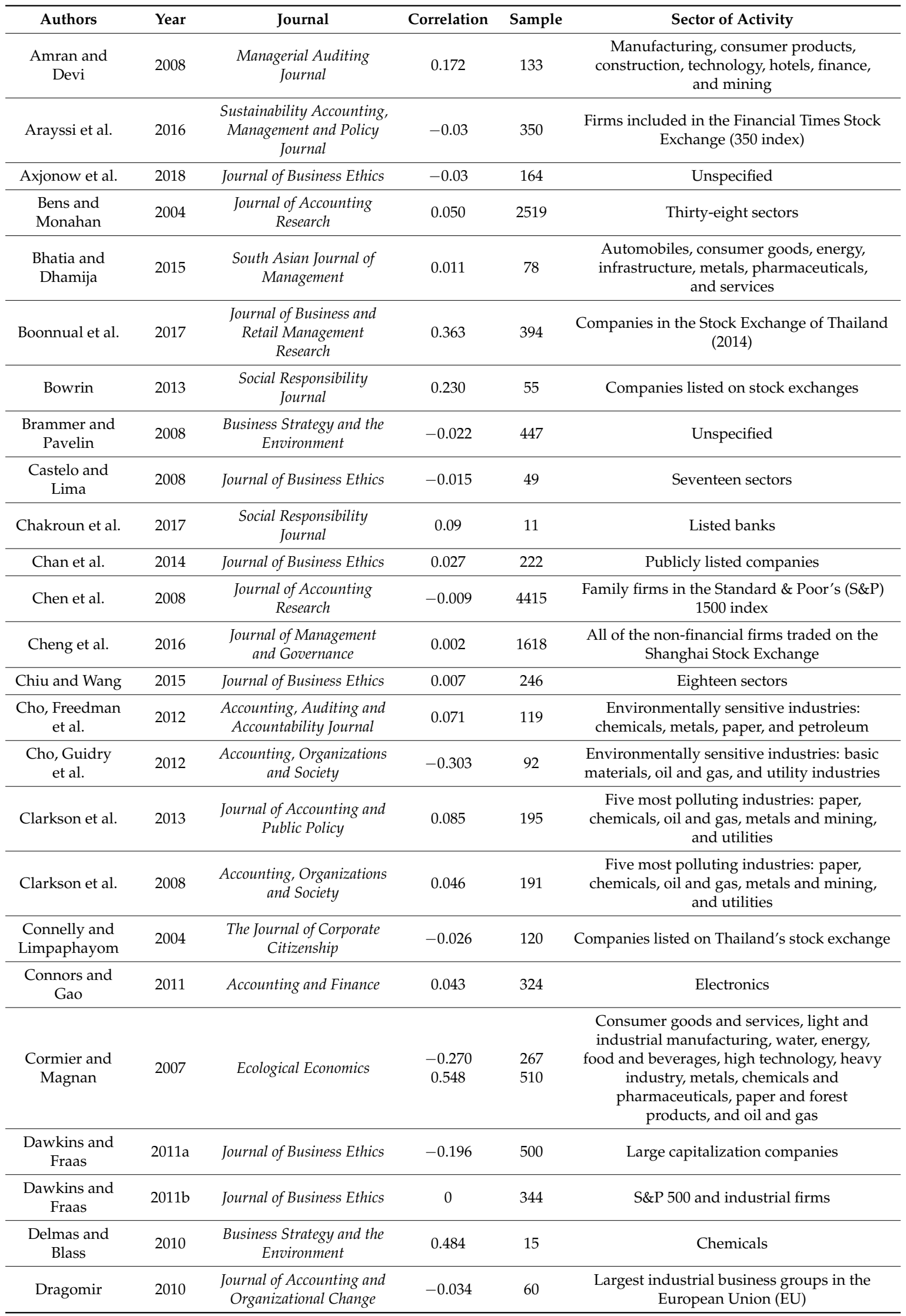


Table 2. Cont.

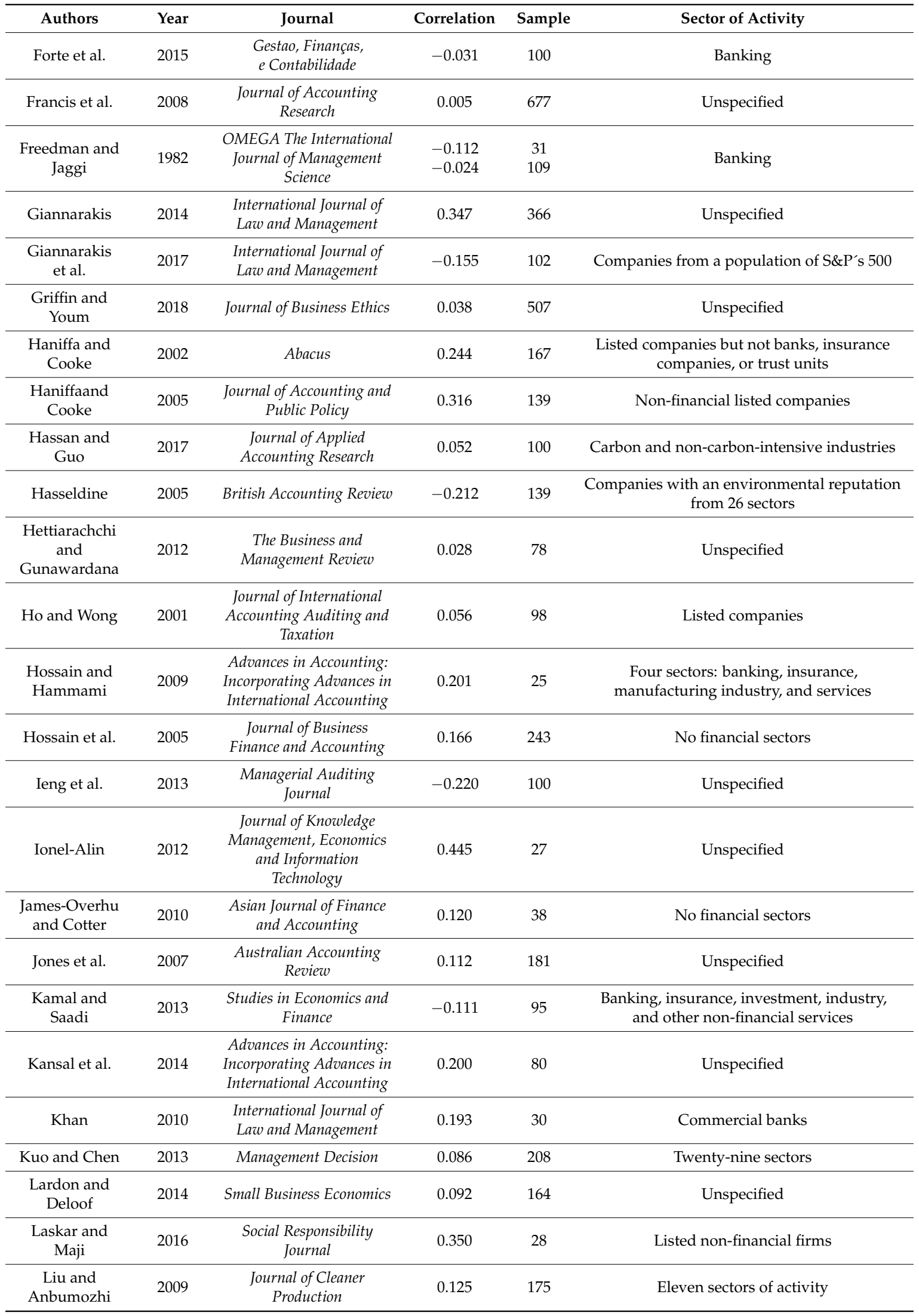


Table 2. Cont.

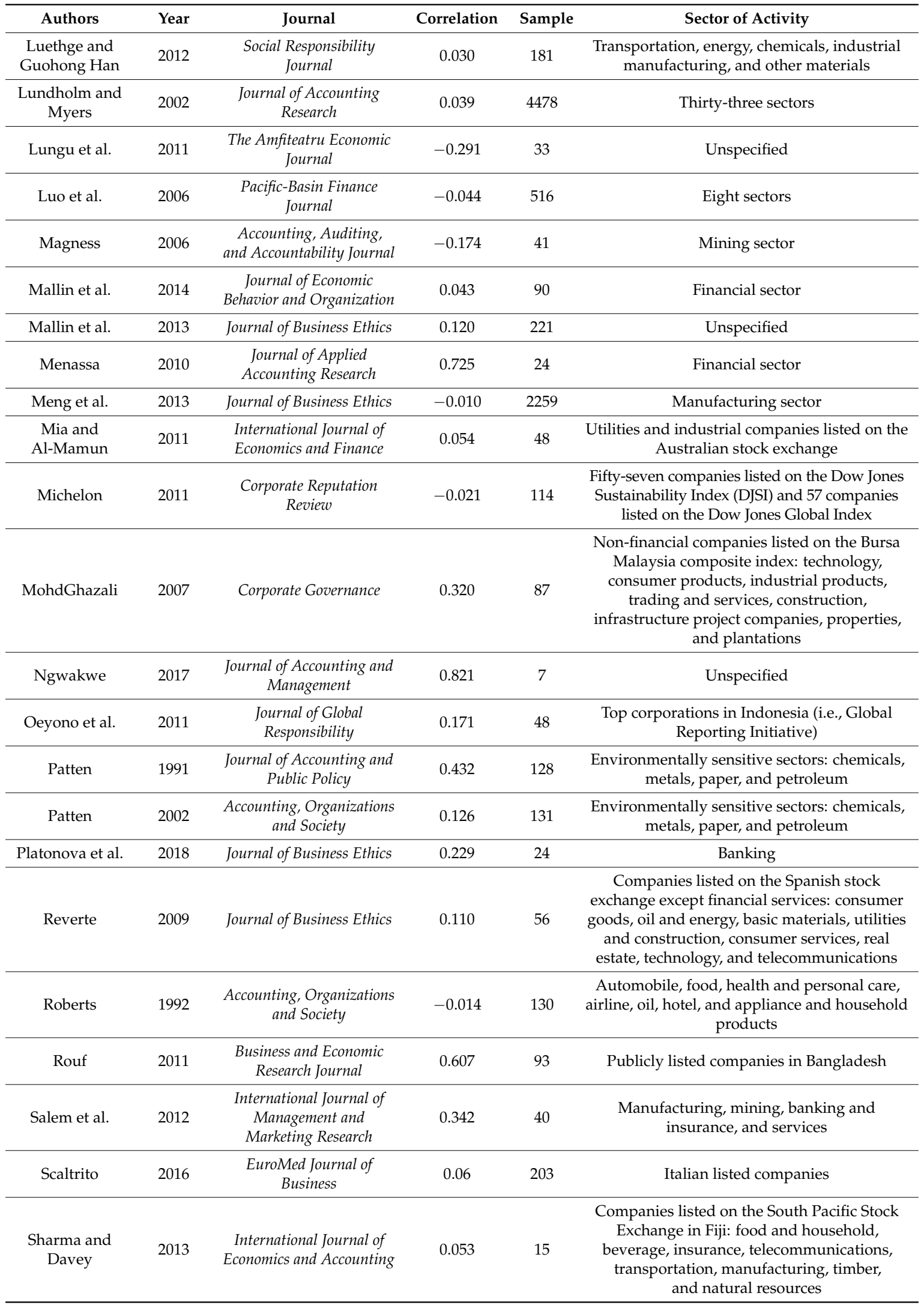


Table 2. Cont.

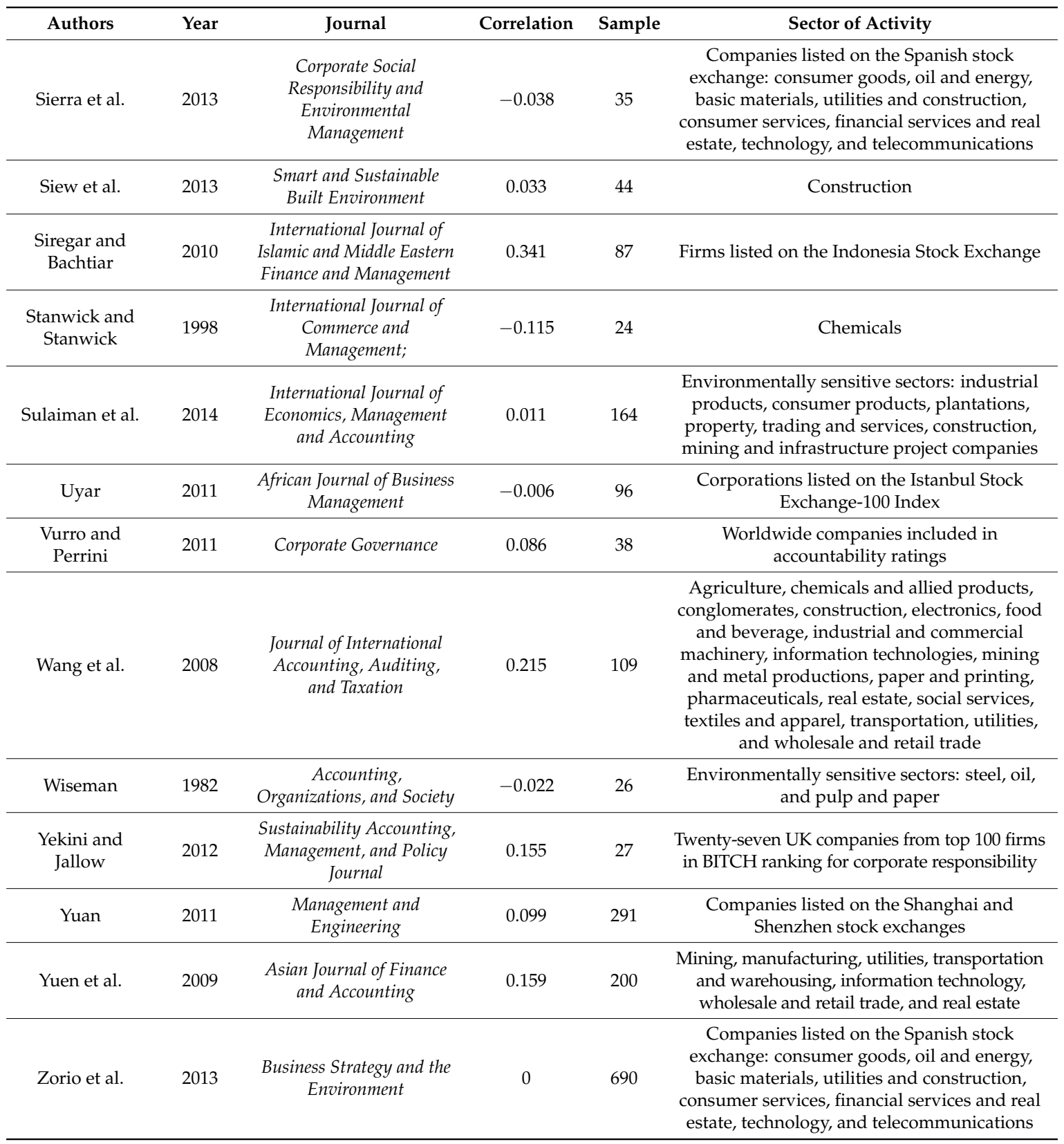

\subsection{Statistical Analysis}

To conduct our statistical analysis, we chose the method developed by Hunter and Schmidt [150], which is the most commonly used in the field of economics [52,53] and is the method previously utilized in Barroso-Méndez et al.'s [151] meta-analysis. The effect size index used to measure the link between CSRD and performance was the Pearson correlation coefficient $(r)$. In order to estimate the effect size, we obtained an $r$ from each independent sample included in the work. The authors of articles that did not provide correlations were contacted by e-mail to obtain those data.

This step involved finding the $r$ or relevant transformation. Following Peterson and Brown's [152] example, the present study also included those works that only offered standardized regression (i.e., beta $[\beta]$ ) coefficients. Peterson and Brown [152] suggest transforming these coefficients into correlation coefficients with Equation (1):

$$
r=0.98 \beta+0.05 \lambda
$$


in which $\lambda$ is an indicator variable that equals 1 when $\beta$ is nonnegative and 0 when $\beta$ is negative. The above formula can only be used with $\beta$ values between -0.5 and +0.5 [152]. We then followed Barroso-Méndez et al.'s [151] procedure to test whether the mean levels of correlations were the same for the two groups: the documents that provided correlations directly and the articles whose correlations were obtained indirectly from their standardized regression coefficients. To this end, a $t$-test assuming equal variances was performed. The findings confirm that no significant differences exist between the two groups for the CSRD-performance relationship, at a significance level of $5 \%$.

Once the coefficients were obtained, we followed Hunter and Schmidt's [150] suggestions and carried out the series of calculations described below. We first calculated the weighted mean of the correlations utilizing Equation (2):

$$
\bar{r}=\frac{\sum N_{i} r_{i}}{\sum N_{i}}
$$

Then we computed the goodness of fit measures by defining a confidence interval of $95 \%$ using Equation (3):

$$
\bar{r} \pm 1.96 \cdot \frac{1-\bar{r}^{2}}{\sqrt{\sum N_{i}-k}}
$$

Next, we calculated the observed total variance of the empirical correlations utilizing Equation (4):

$$
S_{r}^{2}=\frac{\sum N_{i}\left(r_{i}-\bar{r}\right)^{2}}{\sum N_{i}}
$$

Wealso estimated the sampling error variance using Equation (5):

$$
S_{e}^{2}=\frac{\left(1-\bar{r}^{2}\right)^{2}}{\bar{N}-1}
$$

in which $N_{i}$ is the sample size of the $i$-th study, $\bar{r}$ is a weighted mean of the empirical correlations obtained with Equation (2), and $\bar{N}$ is the mean sample size. $\bar{N}=\sum \frac{N_{i}}{k}, k$ is considered the number of studies. Publication bias was assessed by constructing a funnel plot using the trim-and-fill method, as well as conducting the Begg and Mazumdar test [153].

After having estimated the observed variance and sampling error variance, we checked whether the correlations were homogeneous. We verified whether the observed variance was mainly due to a statistical artifact or part of the observed variance due to the influence of moderating variables. Hunter and Schmidt [150] suggest a statistical test can be used for this purpose, which consists of applying the $Q$-statistic using Equation (6):

$$
Q=k\left(\frac{S_{r}^{2}}{S_{e}^{2}}\right)
$$

The $Q$-statistic is distributed according to Pearson's chi-squared distribution with $k-1$ degrees of freedom. The alpha $(\alpha)$ is adopted as the test's significance level so that, if the value given by Equation (6) exceeds the $100(1-\alpha)$ percentile of the distribution, then the homogeneity hypothesis does not hold. In this case, moderating variables need to be found that explain the observed heterogeneity.

In the present study of the CSRD-performance relationship, the following types of calculations were carried out:

1. Estimates with and without large samples to verify the impact of large samples on research results

2. Subgroup analyses of the following moderating variables: performance dimensions, CSRD dimensions, sector of activity, region, type of organization, and measures of organization size.

In the next section, the results of the current research are discussed. All the statistical analyses were programmed in Excel specifically for this study.

\section{Results}

The findings for each of the relationships considered in the meta-analysis are shown in Table 3. 
Table 3. Meta-analysis results.

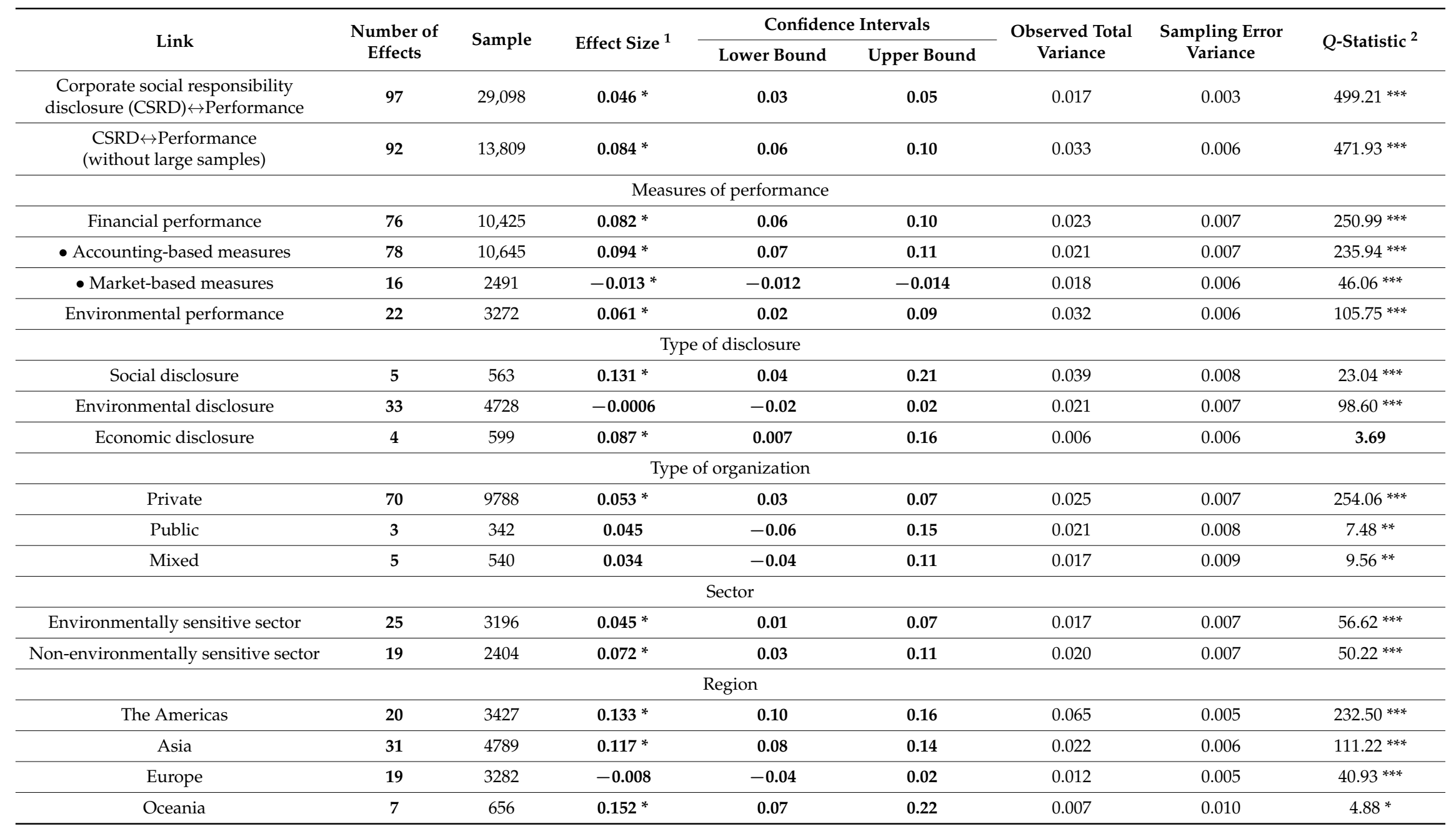


Table 3. Cont

\begin{tabular}{|c|c|c|c|c|c|c|c|c|}
\hline \multirow{2}{*}{ Link } & \multirow{2}{*}{$\begin{array}{l}\text { Number of } \\
\text { Effects }\end{array}$} & \multirow{2}{*}{ Sample } & \multirow{2}{*}{ Effect Size ${ }^{1}$} & \multicolumn{2}{|c|}{ Confidence Intervals } & \multirow{2}{*}{$\begin{array}{l}\text { Observed Total } \\
\text { Variance }\end{array}$} & \multirow{2}{*}{$\begin{array}{l}\text { Sampling Error } \\
\text { Variance }\end{array}$} & \multirow{2}{*}{$Q$-Statistic ${ }^{2}$} \\
\hline & & & & Lower Bound & Upper Bound & & & \\
\hline \multicolumn{9}{|c|}{ Measures of organization size } \\
\hline Log of total assets & 27 & 4653 & $0.079 *$ & 0.051 & 0.108 & 0.037 & 0.005 & $175.48^{* * *}$ \\
\hline Total assets & 14 & 1728 & $0.159 *$ & 0.113 & 0.205 & 0.038 & 0.007 & $69.32 * * *$ \\
\hline Log of total sales & 4 & 685 & 0.042 & -0.032 & 0.117 & 0.020 & 0.005 & $13.83^{* * *}$ \\
\hline Total sales & 3 & 245 & $-0.173 *$ & -0.051 & -0.295 & 0.014 & 0.011 & 3.72 \\
\hline Log of market capitalization & 4 & 217 & $0.136 *$ & 0.004 & 0.267 & 0.013 & 0.018 & 3.08 \\
\hline Market capitalization & 4 & 577 & $0.119 *$ & 0.038 & 0.200 & 0.019 & 0.006 & $11.41^{* * *}$ \\
\hline Log of revenues & 5 & 556 & $0.145 *$ & 0.064 & 0.227 & 0.026 & 0.008 & $15.43^{* * *}$ \\
\hline
\end{tabular}

${ }^{1 *}$ in the effect size column means that the mean correlation is significant. ${ }^{2 *},{ }^{* *}$, and ${ }^{* * *}$ in the $Q$-statistic column means significance at $p<0.1, p<0.05$ and $p<0.01$, respectively. 
The CSRD-organizational performance relationship has an average effect size of 0.04 for the 97 effect sizes in the sample, which corresponds to 29,098 organizations. Five large samples represented a total of 15,289 organizations, so we verified their impact on the average $r$ coefficient. We found that including these samples resulted in a decrease in sampling error variance (i.e., less homogeneity). Thus, the five samples were deleted from our results.

For the general data without the large samples, we obtained a correlation coefficient of 0.08 . Although this effect is statistically significant (see the confidence intervals column in Table 3 above), we chose to apply the scale developed by Cohen [154] for social science research. According to the cited author, correlations with values of $r$ close to $0.1,0.3$, and 0.5 correspond to low, moderate, and high effect sizes, respectively. Based on this scale, the general data's correlation coefficient is not large enough to be considered significant for practical purposes $(<0.1)$.

To assess whether publication bias might be a threat to the validity of the meta-analysis's results, a funnel plot was constructed. Figure 1 shows the funnel plot applied to the 97 effect sizes. An absence of clear asymmetry in a funnel plot can be interpreted as evidence against publication bias. As can be seen, the funnel plot below does not show clear asymmetry on the left side. In addition, when the trim-and-fill method for imputing missing effect sizes was applied to this funnel plot, no missing data were imputed to summarize the funnel plot. However, the Begg and Mazumdar test's [153] results were statistically significant (tau $=0.13 ; p=0.049$ ). Regardless of this test's significant results [153], publication bias can be discarded as a threat against the validity of the present meta-analysis's results.

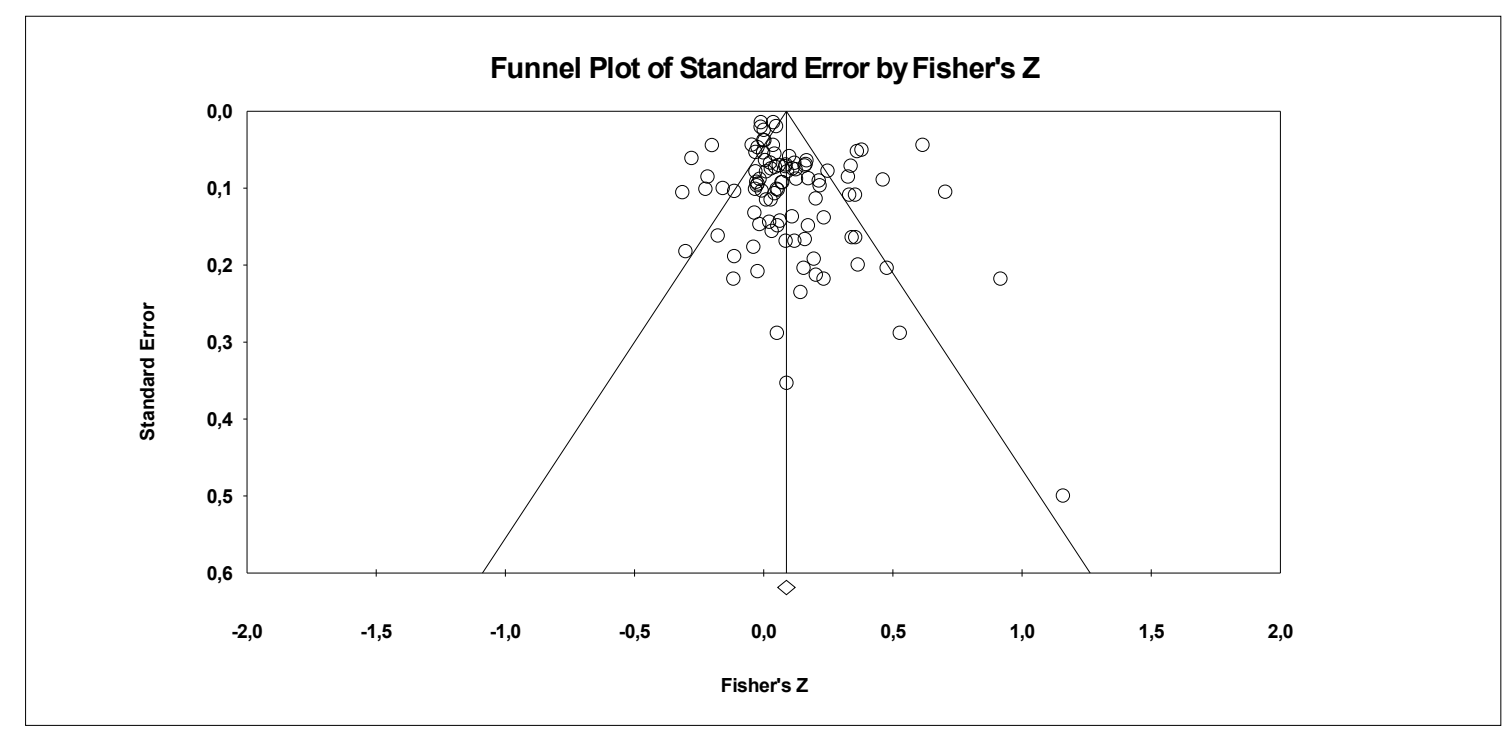

Figure 1. Funnel plot of Pearson correlation coefficients. Note: to construct this figure, Fisher's $r$-to- $z$ transformation of the correlation coefficients was applied.

Due to the high variability in the correlations of the studies included in the final sample, we rejected the null hypothesis of homogeneity (see the $Q$-statistic column in Table 3 above). This finding suggested further analysis of moderating effects was needed. For this purpose, we grouped the studies according to their similar characteristics in terms of the moderator variables discussed previously.

The first group reflected how the findings on a CSRD-performance link are likely to be influenced by the type of performance measure employed. The two performance measures considered-financial performance and environmental performance-have similar effect sizes, which are slightly lower than the global effect size $(0.082,0.061<0.084)$, and statistically significant for both measures (see the confidence intervals column in Table 3 above). Although these effect sizes are statistically significant, according to Cohen's [154] scale, these correlations are not strong enough to be considered significant for practical purposes $(<0.1)$. 
In addition, some studies focused on financial performance have used accounting-based measures, while other researchers have applied market-based measures. The present results show that accounting-based measures have a higher effect size than the global effect size $(0.094>0.084)$, but market-based measures have a lower effect size than the global effect size $(-0.013<0.084)$. These findings coincide with other researchers' conclusions in the literature. For example, Allouche and Laroche [52] conducted a meta-analytical investigation of the relationship between corporate social and financial performance. The cited authors confirmed that studies using accounting-based measures tend to find a stronger link between the variables under study than do studies utilizing market-based measures, in which the effect size obtained is close to zero. Although the reported effect sizes are statistically significant, Cohen's [154] scale again indicates that the correlations are not strong enough to be considered significant for practical purposes $(<0.1)$.

Regarding the second group of studies in the present meta-analysis's sample, the CSRD-performance relationship is also likely to be influenced by the type of CSR information disclosed. The results show that social disclosure's effect size is higher than the effect sizes obtained using environmental and economic disclosure $(0.087,0.131>-0.00006)$. Moreover, according to Cohen's [154] scale, social disclosure's effect size is the only one strong enough to be considered significant for practical purposes $(>0.1)$.

In terms of the third group, Table 3 above shows moderation of the CSRD-performance relationship by type of organization and sector of activity. On the one hand, the two types of sectors considered in the current study-environmentally and non-environmentally sensitive sectors-have lower effect sizes than the global effect size $(0.045,0.072<0.084)$, and these are statistically significant in both types of sectors. Nonetheless, these correlations are again not strong enough to be considered significant for practical purposes $(>0.1)$. In contrast, different types of organizations-private, public, and mixed — have similar effect sizes that are lower than the general effect size $(0.053,0.045$, $0.034<0.084)$. As in the previous case, Cohen's [123] scale indicates that these correlations are not strong enough to be considered significant for practical purposes $(<0.1)$.

In the fourth group of moderation by the variable region, the regions-with the exception of Europe-(i.e., the Americas, Asia, and Oceania) present larger effect sizes than the general effect size $(0.133,0.117,0.152>0.084)$. These regions' correlations are also statistically significant and strong enough to be considered significant for practical purposes $(>0.1)$.

Regarding the last group, the CSRD-performance relationship is also likely to be influenced by the measures of organization size utilized. With the exception of the logs of total assets and of total sales, the measures considered (i.e., total assets, total sales, log of market capitalization, market capitalization, and log of revenues) present larger effect sizes than the general effect size $(0.159,-0.173$, $0.136,0.119,0.145>0.084)$. The correlations of these size measures are statistically significant, and they are significant enough for practical purposes $(>0.1)$. Notably, when organization size is measured by total sales, the CSRD-performance relationship is negative, which can be considered a finding of vital importance to organizations' managers.

After analyzing these results, we rejected hypothesisH1 because the link between CSRD and organizational performance is insignificant for all practical purposes. Hypotheses H2, H3, H5, and H6 were also rejected because the methods used to measure overall or financial performance, type of organization, and sector of activity have no moderation effect. However, the results confirm hypotheses $\mathrm{H} 4, \mathrm{H} 7$, and $\mathrm{H} 8$, which posited the moderating role of type of disclosure, region under study, and measures of organization size.

\section{Conclusions}

The general impression persists even now in the literature that researchers' results are, in the aggregate, inconclusive regarding any theoretical findings about the CSRD-performance relationship. The results of the present meta-analysis confirm that the correlation between CSRD and performance is not significant enough for practical purposes, which coincides with previous studies' results [72-76] that found no clear relationships between the variables under study. However, in order to delve more 
deeply into the nature of the CSRD-performance link, the current research included an analysis of moderating variables.

First, our results demonstrate, in line with previous studies [54,153], that the type of disclosed information moderates the relationship between CSRD and performance. However, in contrast to Miras-Rodriguez et al.'s [54] findings, which highlight the importance of disclosing environmental information, the present meta-analysis's results emphasize the value of disseminating social information. This finding could shape managers' approach by encouraging them to pay more attention to disclosing the latter type of information.

Second, our results are also consistent with different authors' suggestion $[54,155,156]$ that the region under study moderates the CSRD-performance connection. More specifically, the current research found that, in the three regions of the Americas, Asia, and Oceania, the relationship can be considered significant for practical purposes. This finding could be quite important to different organizations' managers. Given regional cultures' influence on the relationship under study, administrators need to develop strategies to manage these differences.

Last, our results show that organization size measures moderate the relationship between CSRD and performance. More specifically, we found that five measures-total assets, total sales, the log of market capitalization, market capitalization, and the log of revenues-present correlations with a magnitude considered significant enough for practical purposes. Therefore, the choice between employing one or another of these five measure has theoretical and empirical implications even when all the measures of organization size are suitable. More specifically, given the effect sizes obtained in our meta-analysis, the most appropriate way to assess organization size in this field of research is "total assets" because of this measure's higher effect size in relation to the remaining measures studied.

Therefore, our study makes important empirical contributions to the discussion of the relationship existing between the two main variables, as well as key moderating variables that can explain the variable results of previous research.

This study also has important practical implications. Our findings are extremely useful because managers can use this deeper understanding of the connection between CSRD and organizational performance to guide their plans for-and implementation and maintenance of-initiatives seeking to strengthen both variables. In addition, this research's results also have important policy implications for standard setters that seek to define internationally accepted reporting standards for companies and institutional investors worldwide, thereby potentially affecting companies' future performance.

Regarding this study's limitations, we need to highlight that meta-analytic studies have inherent shortcomings [157]. First, the main research objectives were to determine whether a relationship exists between CSRD and performance and, more specifically, whether the connection is positive or negative, as well as determining its magnitude. To this end, we opted to carry out a standard meta-analysis. In this type of meta-analysis, the effect size index used to measure the links between the variables under study is the Pearson correlation coefficient. Given that this correlation does not imply causality, we did not need to include any empirical treatment to deal with the problem of endogeneity. However, future papers may want to test competing directions in the CSRD-performance relationship by employing a multivariate model and regression analysis (i.e., meta-regression), which is more appropriate for this specific objective. This type of study should consider Li's [158] suggestions for how to mitigate-to the extent possible - the problem of endogeneity.

Second, the present research, similar to other meta-analyses [151], included only works that reported Pearson correlation coefficients and standardized $\beta$ coefficients. The current research could be developed into future analyses that include studies that, although they do not disclose these statistical data, still offer sufficient information for adequate processing.

Further research is also needed to continue extending the understanding of CSRD and organizational performance's links to the variables included in the current study, which were those most extensively examined in the literature. Future research could also include the connections that have been less frequently analyzed, for example, between the different subdimensions of the main 
variables under study (i.e., CSRD and performance). As already noted previously, the heterogeneous results for these two variables - even after including different aggregates as moderating variables-also underline the need for additional research. More studies are thus needed to examine if other moderating variables are relevant to the CSRD-performance relationship. For example, corporate governance's impact on organizations' performance and dissemination of information has been demonstrated by different authors $[42,45,50]$, so this variable would be interesting to include.

Supplementary Materials: PRISMA checklist is available online at http:/ / www.mdpi.com/2071-1050/11/4/ $1115 /$ s1.

Author Contributions: All the listed authors contributed to this research's development. More specifically, D.G.-V. reviewed the literature and analyzed the papers under study to collect data for the meta-analysis; wrote the part of the manuscript dealing with the literature's evolution; and conducted analyses of the results and provided support for conclusions. M.J.B.-M. designed the research, reviewed the literature, analyzed the data collected, wrote up the empirical part of the methodology, and contributed to the results and discussion sections. M.L.P.-M. also reviewed the literature and analyzed the papers under study, thereby collecting data for the meta-analysis, and wrote the section on the development of objectives and hypotheses. In addition, the three authors reviewed the manuscript's final version and approved it. J.S.-M. contributed his extensive knowledge of meta-analysis methodology, thereby supporting the development of the empirical methodology applied, the practical analysis, and the overall discussion of the results.

Funding: This research was supported by a grant from the Business Research (INVE) Research Group (Code: SEJ022) and also from M@rkDO (Code: SEJ021), both listed in Autonomous Community of Extremadura.

Conflicts of Interest: The authors declare no conflict of interest.

\section{Appendix A. Final List of Documents Used in Meta-analysis (Alphabetical Order)}

Adelopo, I. Voluntary Disclosure Practices Amongst Listed Companies in Nigeria. Adv. Account. 2011, 27, 338-345, doi:10.1016/j.adiac.2011.08.009.

Aerts, W.; Cormier, D. Media Legitimacy and Corporate Environmental Communication. Account. Organ. Soc. 2009, 34, 1-27, doi:10.1016/j.aos.2008.02.005.

Agca, A.; Önder, S. Voluntary Disclosure in Turkey: A Study on Firms Listed in Istanbul Stock Exchange (ISE). Probl. Perspect. Manag. 2007, 5(3), 241.

Agyei-Mensah, B.K. Association Between Firm-specific Characteristics and Levels of Disclosure of Financial Information of Rural Banks in the Ashanti region of Ghana. J. Appl. Financ. Bank. 2012, 2(1), 69-92, doi:10.2139/ssrn.1840423.

Ahmad, Z.; Hassan, S.; Mohammad, J. Determinants of Environmental Reporting in Malaysia. Int. J. Bus. Stud. 2003, 11(1), 69-90.

Ahmadi, A.; Bouri, A. The Relationship Between Financial Attributes, Environmental Performance and Environmental Disclosure. Empirical Investigation on French Firms Listed on CAC 40. Manag. Environ. Qual. Int. J. 2017, 28(4), 490-506, doi:10.1108/MEQ-07-2015-0132.

Al-Ajmi, M.; Al-Mutairi, A.; Al-Duwaila, N. Corporate Social Disclosure Practices in Kuwait. Int. J. Econ. Financ. 2015, 7(9), 244-254, doi:10.5539/ijef.v7n9p244.

Albitar, K. Firm Characteristics, Governance Attributes and Corporate Voluntary Disclosure: A Study of Jordanian Listed Companies. Int. Bus. Res. 2015, 8(3), 1-10, doi:10.5539/ibr.v8n3p1.

Al-Tuwaijri, S.A.; Christensen, T.E.; Hughes, K.E. The Relations Among Environmental Disclosures, Environmental Performance, and Economic Performance: A Simultaneous Equations Approach. Account. Organ. Soc. 2004, 29 (5-6), 447-471, doi:10.1016/S0361-3682(03)00032-1.

Amran, A.; Devi, S.S. The Impact of Government and Foreign Affiliate Influence on Corporate Social Reporting: The Case of Malaysia. Manag. Audit. J. 2008, 23(4), 386-404, doi:10.1108/02686900810864327.

Arayssi, M.; Dah, M.; Jizi, M. Women on Boards, Sustainability Reporting and Firm Performance. Sustain. Account. Manag. Policy J. 2016, 7(3), 376-401, doi:10.1108/SAMPJ-07-2015-0055. 
Axjonow, A.; Ernstberger, J.; Pott, C. The Impact of Corporate Social Responsibility Disclosure on Corporate Reputation: A Non-professional Stakeholder Perspective. J. Bus. Ethics 2018, 151, 429-450, doi:10.1007/s10551-016-3225-4.

Bens, D.A.; Monahan, S.J. Disclosure Quality and the Excess Value of Diversification. J. Account. Res. 2004, 42(4), 691-730, doi:10.1111/j.1475-679X.2004.00154.x.

Bhatia, M.; Dhamija, S. Voluntary Disclosure of Financial Ratios in India. S. Asian. J. Manag. 2015, 22(1), $28-49$.

Boonnual, C.; Prasertsri, W; Panmanee, P. Corporate Social Responsibility and Firm Performance in Thailand. J. Bus. Retail Manag. Res. 2017, 12(1), 169-177, doi:10.24052/JBRMR/V12IS01/CSRAFPIT.

Bowrin, A.R. Corporate Social and Environmental Reporting in the Caribbean. Soc. Responsib.J. 2013, 9(2), 259-280, doi:10.1108/SRJ-08-2011-0074.

Brammer, S.; Pavelin, S. Factors Influencing the Quality of Corporate Environmental Disclosure. Bus. Strat. Environ. 2008, 17, 120-136, doi:10.1002/bse.506.

Castelo Branco, M.; Lima Rodriguez, L. Factors Influencing Social Responsibility Disclosure by Portuguese Companies. J. Bus. Ethics 2008, 83, 685-701, doi:10.1007/s10551-007-9658-z.

Chakroun, R.; Matoussi, H.; Mbirki, S. Determinants of CSR Disclosure of Tunisian Listed Banks: A Multi-support Analysis. Soc. Responsib. J. 2017, 13(3), 552-584, doi:10.1108/SRJ-04-2016-0055.

Chan, M.C.; Watson, J.; Woodliff, D. Corporate Governance Quality and CSR Disclosures. J. Bus. Ethics 2014, 125, 59-73, doi:10.1007/s10551-013-1887-8.

Chen, S.; Chen, X.; Cheng, Q. Do Family Firms Provide More or Less Voluntary Disclosure? J. Account. Res. 2008, 46(3), 499-536, doi:10.1111/j.1475-679X.2008.00288.x.

Cheng, S.; Lin, K.Z.; Wong, W. Corporate Social Responsibility Reporting and Firm Performance: Evidence from China. J. Manag. Gov. 2016, 20, 503-523, doi:10.1007/s10997-015-9309-1.

Chiu, T.K.; Wang, Y.H. Determinants of Social Disclosure Quality in Taiwan: An Application of Stakeholder Theory. J. Bus. Ethics 2015, 129, 379-398, doi:10.1007/s10551-014-2160-5.

Cho, C.H.; Freedman, M.; Patten, D.M. Corporate Disclosure of Environmental Capital Expenditures. A Test of Alternative Theories. Account. Audit. Account. J. 2012, 25(3), 486-507, doi:org/10.1108/09513571211209617.

Cho, C.H.; Guidry, R.P.; Hageman, A.M.; Patten, D.M. Do Actions Speak Louder Than Words? An Empirical Investigation of Corporate Environmental Reputation. Account. Organ. Soc. 2012, 37, 14-25, doi:10.1016/j.aos.2011.12.001.

Clarkson, P.M.; Fang, X.; Li, Y.; Richardson, G. The Relevance of Environmental Disclosures: Are Such Disclosures Incrementally Informative? J. Account. Public Policy. 2013, 32, 410-431, doi:10.1016/j.jaccpubpol.2013.06.008.

Clarkson, P.M.; Li, Y.; Richardson, G.D.; Vasvari, F.P. Revisiting the Relation Between Environmental Performance and Environmental Disclosure: An Empirical Analysis. Account. Organ. Soc. 2008, 33, 303-327, doi:10.1016/j.aos.2007.05.003.

Connelly, J.T.; Limpaphayom, P. Environmental Reporting and Firm Performance: Evidence From Thailand. J. Corp. Citizensh. 2004, 13, 137-149.

Connors, E.; Gao, L.S. Corporate Environmental Performance, Disclosure and Leverage: An Integrated Approach. Int. Rev. Account. Bank. Financ. 2011, 3(3), 1-26.

Cormier, D.; Magnan, M. The Revisited Contribution of Environmental Reporting to Investors' Valuation of a Firm's Earnings: An International Perspective. Ecol. Econ. 2007, 62, 613-626, doi:10.1016/j.ecolecon.2006.07.030.

Dawkins, C.E.; Fraas, J.W. Coming Clean: The Impact of Environmental Performance and Visibility on Corporate Climate Change Disclosure. J. Bus. Ethics 2011a, 100, 303-322, doi:10.1007/s10551-010-0681-0.

Dawkins, C.E.; Fraas, J.W. Erratum to Beyond Acclamations and Excuses: Environmental Performance, Voluntary Environmental Disclosure and the Role of Visibility. J. Bus. Ethics 2011b, 99, 383-397, doi:10.1007/s10551-010-0659-y. 
Delmas, M.; Blass, V.D. Measuring Corporate Environmental Performance: The Trade-Offs of Sustainability Ratings. Bus. Strat. Environ. 2010, 19, 245-260, doi:10.1002/bse.676.

Dragomir, V.D. Environmentally Sensitive Disclosures and Financial Performance in a European Setting. J. Account. Organ. Change. 2010, 6(3), 359-388, doi: 10.1108/18325911011075222.

Forte, L.M.; Neto, J.B.; Nobre, F.C.; Nobre, L.H.; Queiroz, D.B. Determinants of Voluntary Disclosure: A Study in the Brazilian Baking Sector. Rev. Gest. Financ. Contab. 2015, 5(2), 23-37, doi:10.1017/CBO9781107415324.004.

Francis, J.; Nanda, D.; Olsson, P. Voluntary Disclosure, Earnings Quality, and Cost of Capital. J. Account. Res. 2008, 46(1), 53-99, doi:10.1111/j.1475-679X.2008.00267.x.

Freedman, M.; Jaggi, B. Pollution Disclosures, Pollution Performance and Economic Performance. OMEGA, Int. J. Manag. Sci. 1982, 10(2), 167-176, doi:10.1016/0305-0483(82)90051-2.

Giannarakis, G. The Determinants Influencing the Extent of CSR Disclosure. Int. J. Law Manag. 2014, 56(5), 393-416, doi:10.1108/IJLMA-05-2013-0021\}.

Giannarakis, G.; Konteos, G.; Sariannidis, N.; Chaitidis, G. The Relation Between Voluntary Carbon Disclosure and Environmental Performance. The Case of S\&P 500. Int. J. Law Manag. 2017, 59(6), 784-803, doi:10.1108/IJLMA-05-2016-0049.

Griffin, J.J.; Youm, Y.N. Voluntarily Disclosing Prosocial Behaviors in Koreans Firms. J. Bus. Ethics 2018, 153(4), 1017-1030, doi:10.1007/s10551-018-3915-1.

Haniffa, R.M.; Cooke, T.E. Culture, Corporate Governance and Disclosure in Malaysian Corporations. Abacus. 2002, 38(3), 317-349, doi:10.1111/1467-6281.00112.

Haniffa, R.M.; Cooke, T.E. The Impact of Culture and Governance on Corporate Social Reporting. J. Account. Public Policy. 2005, 24, 391-430, doi:10.1016/j.jaccpubpol.2005.06.001.

Hassan, A.; Guo, X. The Relationships Between Reporting Format, Environmental Disclosure and Environmental Performance. An Empirical Study. J. Appl. Account. Res. 2017, 18(4), 425-444, doi:10.1108/JAAR-06-2015-0056.

Hasseldine, J.; Salama, A.I.; Toms, J.S. Quantity Versus Quality: The Impact of Environmental Disclosures on the Reputations of UK PLCs. Brit. Account. Rev. 2005, 37(2), 231-248, doi:10.1016/j.bar.2004.10.003.

Hettiarachchi, D.C.; Gunawardana, K.D. The Impact of Corporate Social Responsibility Reporting (CSRR) on Financial Performance-Empirical Evidence from Sri Lanka. Bus. Manag. Rev. 2012, 2(1), 66-77.

Ho, S.S.M.; Wong, K.S. A Study of the Relationship Between Corporate Governance Structures and the Extent of Voluntary Disclosure. J. Int. Acc. Audit Tax 2001, 10, 139-156, doi:org/10.1016/S1061-9518(01)00041-6.

Hossain, M.; Ahmed, K.; Godfrey, J.M. Investment Opportunity Set and Voluntary Disclosure of Prospective Information: A Simultaneous Equations Approach. J. Bus. Financ. Account. 2005, 32(5-6), 871-907, doi:10.1111/j.0306-686X.2005.00616.x.

Hossain, M.; Hammami, H. Voluntary Disclosure in the Annual Reports of an Emerging Country: The Case of Qatar. Adv.Account. 2009, 25, 255-265, doi:10.1016/j.adiac.2009.08.002.

Ieng, C.; Chatterjee, B.; Brown, A. The Current Status of Greenhouse Gas Reporting by Chinese Companies. A Test of Legitimacy Theory. Manag. Audit J. 2013, 28(2), 114-139, doi:org/10.1108/02686901311284531.

Ionel-Alin, I. Analyze of Environmental Disclosure Within European Union Countries. J. Knowl. Manag. Econ. Inf. Technol. 2012, 4 .

James-Overheu, C.; Cotter, J. Corporate Governance, Sustainability and the Assessment of Default Risk. Asian J. Financ. Account. 2010, 1(1), 34-53.

Jekini, K.; Jallow, K. Corporate Community Involvement Disclosures in Annual Reports. A Measure of Corporate Community Development or a Signal of CSR Observance? Sustain. Account. Manag. Policy J. 2012, 3(1), 7-32, doi:10.1108/20408021211223534. 
Jones, S.; Frost, G.; Loftus, J.;Van der Laan, S. An Empirical Examination of the Market Returns and Financial Performance of Entities Engages in Sustainability Reporting. Aust. Account. Rev. 2007, 17(1), 78-87, doi:10.1111/j.1835-2561.2007.tb00456.x.

Kamal, M.; Saadi, S. Corporate Governance, Economic Turbulence and Financial Performance of UAE Listed Firms. Stud. Econ. Financ. 2013, 30(2), 118-138, doi:10.1108/10867371311325435\}.

Kansal, M.; Joshi, M.; Batra, G.S. Determinants of Corporate Social Responsibility Disclosures: Evidence from India. Adv. Account. 2014, 30, 217-229, doi:10.1016/j.adiac.2014.03.009.

Khan, H. The Effect of Corporate Governance Elements on Corporate Social Responsibility (CSR) Reporting: Empirical Evidence from Private Commercial Banks of Bangladesh. Int. J. Law Manag. 2010, 52(2), 82-109, doi:org/10.1108/17542431011029406.

Kuo, L.; Chen, C.Y.J. Is Environmental Disclosure an Effective Strategy on Establishment of Environmental Legitimacy for Organization? Manag. Decis. 2013, 51(7), 1462-1487, doi:org/10.1108/MD-06-2012-0395.

Lardon, A.; Deloof, M. Financial Disclosure by SMEs Listed on a Semi-regulated Market: Evidence from the Euronext Free Market. Small Bus. Econ. 2014, 42, 361-385, doi:10.1007/s11187-013-9484-x.

Laskar, N.; Maji, S.G. Corporate Sustainability Reporting Practices in India: Myth or Reality? Soc. Responsib. J. 2016, 12(4), 625-641, doi:10.1108/SRJ-05-2015-0065.

Liu, X.; Anbumozhi, V. Determinants Factors of Corporate Environmental Information Disclosure: An Empirical Study of Chinese Listed Companies. J. Clean. Prod. 2009, 17, 593-600, doi:10.1016/j.jclepro.2008.10.001.

Luethge, D.; Guohong Han, H. Assessing Corporate Social and Financial Performance in China. Soc. Responsib. J. 2012, 8(3), 389-403, doi:10.1108/17471111211247965.

Lundholm, R.; Myers, L.A. Bringing the Future Forward: The Effect of Disclosure on the Returns-Earnings Relation. J. Account. Res. 2002, 40(3), 809-839, doi:10.1111/1475-679X.00072.

Lungu, C.I.; Caraiani, C.; Dascalu, C. Research on Corporate Social Responsibility Reporting. Amfiteatru Econ. 2011, 29, 117-131.

Luo, S.; Courtenay, S.M.; Hossain, M. The Effect of Voluntary Disclosure, Ownership Structure and Proprietary Cost on the Return-future Earnings Relation. Pac.-Basin Financ. J. 2006, 14, 501-521, doi:10.1016/j.pacfin.2006.02.002.

Magness, V. Strategic Posture, Financial Performance and Environmental Disclosure. An Empirical Test of Legitimacy Theory. Account. Audit. Account. 2006, 19(4), 540-563, doi:org/10.1108/09513570610679128.

Mallin, C.; Farag, H.; Ow-Yong, K. Corporate Social Responsibility and Financial Performance in Islamic Banks. J. Econ. Behav. Organ. 2014, 103, S21-S38, doi:10.1016/j.jebo.2014.03.001.

Mallin. C.; Michelon, G.; Raggi, D. Monitoring Intensity and Stakeholders' Orientation: How Does Governance Affect Social and Environmental Disclosure? J. Bus. Ethics 2013, 114(1), 29-43, doi:10.1007/s10551-012-1324-4.

Menassa, E. Corporate Social Responsibility. An Exploratory Study of the Quality and Extent of Social Disclosures by Lebanese Commercial Banks. J. Appl. Account. Res. 2010, 11(1), 4-23, doi:org/10.1108/09675421011050009.

Meng, X.H.; Zeng, S.X.; Tam, C.M. From Voluntarism to Regulation: A Study on Ownership, Economic Performance and Corporate Environmental Information Disclosure in China. J. Bus. Ethics 2013, 116, 217-232, doi:10.1007/s10551-012-1462-8.

Ngwakwe, C.C. Corporate Health and Safety Disclosure and Sales Revenue Growth. J. Account. Manag. 2017, $7(2), 5-11$.

Mia, P.; Al-Mamun, A. Corporate Social Disclosure During the Global Financial Crisis. Int. J. Econ. Financ. 2011, 3(6), 174-187, doi:org/10.5539/ ijef.v3n6p174.

Michelon, G. Sustainability Disclosure and Reputation: A Comparative Study. Corp. Reput. Rev. 2011, 14(2), 79-96, doi:10.1057/crr.2011.10.

Mohd Ghazali, N.A. Ownership Structure and Corporate Social Responsibility Disclosure: Some Malaysian Evidence. Corp. Gov. 2007, 7(3), 251-266, doi:org/10.1108/14720700710756535. 
Oeyono, J.; Samy, M.; Bampton, R. An Examination of Corporate Social Responsibility and Financial Performance. A Study of the Top 50 Indonesian Listed Corporations. J. Glob. Responsib. 2011, 2(1), 100-112, doi:10.1108/20412561111128555.

Patten, D.M. Exposure, Legitimacy and Social Disclosure. J. Account. Public Policy. 1991, 10, 297-308, doi:org/10.1016/0278-4254(91)90003-3.

Patten, D.M. The Relation Between Environmental Performance and Environmental Disclosure: A Research Note. Account. Organ. Soc. 2002, 27(8), 763-773, doi:10.1016/S0361-3682(02)00028-4.

Platonova, E.; Asutay, M.; Dixon, R.; Mohammad, S. The Impact of Corporate Social Responsibility Disclosure on Financial Performance: Evidence from the GCC Islamic Banking Sector. J. Bus. Ethics 2018, 151, 451-471, doi:org/10.1007/s10551-016-3229-0.

Reverte, C. Determinants of Corporate Social Responsibility Disclosure Ratings by Spanish Listed Firms. J. Bus. Ethics 2009, 88, 351-366, doi:10.1007/s10551-008-9968-9.

Roberts, R.W. Determinants of Corporate Social Disclosure: An Application of Stakeholder Theory. Account. Organ. Soc. 1992, 17(6), 595-612, doi:10.1016/0361-3682(92)90015-K.

Rouf, M.A. The Corporate Social Responsibility Disclosure: A Study of Listed Companies in Bangladesh. Bus. Econ. Res. J. 2011, 2(3), 19-32.

Salem, N.; Kavanagh, M.; Slaughter, G. An Empirical Study of the Relationship Between Corporate Social Responsibility Disclosure and Organizational Performance: Evidence from Libya. Int. J. Manag. Mark. Res. 2012, 5(3), 69-82.

Scaltrito, D. Voluntary Disclosure in Italy. Firm-specific Determinants an Empirical Analysis of Italian Listed Companies. EuroMed J. Bus. 2016, 11(2), 272-303, doi:10.1108/EMJB-07-2015-0032.

Sharma, U.; Davey, H. Voluntary Disclosure in the Annual Reports of Fijian Companies. Int. J. Econ. Account. 2013, 4(2), 184-208, doi:10.1504/IJEA.2013.055172.

Sierra, L.; Zorio, A.; García-Benau, M.A. Sustainable Development and Assurance of Corporate Social Responsibility Reports Published by Ibex-35 Companies. Corp. Soc. Responsib. Environ. Manag. 2013, 20, 359-370, doi:org/10.1002/csr.1303.

Siew, R.Y.J.; Balatbat, M.C.A.; Carmichael, D.G. The Relationship Between Sustainability Practices and Financial Performance of Construction Companies. Smart Sustain. Built Environ. 2013, 2(1), 6-27, doi:org/10.1108/20466091311325827.

Siregar, S.V.; Bachtiar, Y. Corporate Social Reporting: Empirical Evidence from Indonesia Stock Exchange. Int. J. Islamic Middle East. Financ. Manag. 2010, 3(3), 241-252, doi:10.1108/17538391011072435.

Stanwick, S.D.; Stanwick, P.A. Corporate Social Responsiveness: An Empirical Examination Using the Environmental Disclosure Index. Int. J. Commer. Manag. 1998, 8(3/4), 26-40, doi:org/10.1108/eb047373.

Sulaiman, M.; Abdullah, N.; Fatima, A.H. Determinants of Environmental Reporting Quality in Malaysia. Int. J. Econ. Manag. Account. 2014, 22(1), 63-90.

Uyar, A. Firm Characteristics and Voluntary Disclosure of Graphs in Annual Reports of Turkish Listed Companies. Afr. J. Bus. Manag. 2011, 5(17), 7651-7657, doi:10.5897/AJBM11.1094.

Vurro, C.; Perrini, F. Making the Most of Corporate Social Responsibility Reporting: Disclosure Structure and Its Impact on Performance. Corp. Gov. 2011, 11(4), 459-474, doi:org/10.1108/14720701111159280.

Wang, K.; Sewon, O.; Claiborne, M.C. Determinants and Consequences of Voluntary Disclosure in an Emerging Market: Evidence from China. J. Int. Account. Audit. Tax. 2008, 17, 14-30, doi:org/10.1016/j.intaccaudtax.2008.01.001.

Wiseman, J. An Evaluation of Environmental Disclosures Made in Corporate Annual Reports. Account. Organ. Soc. 1982, 7(1), 53-63, doi:org/10.1016/0361-3682(82)90025-3.

Yuan, Y. Research on the Influential Factors of CSR Information Disclosure. Manag. Eng. 2011, 2, 1838-5745, doi:10.5503/J.ME.2011.02.003. 
Yuen, D.C.Y.; Liu, M.; Zhang, X.; Lu, C.A. Case Study of Voluntary Disclosure by Chinese Enterprises. Asian J. Financ. Account. 2009, 1(2), 118-145.

Zorio, A.; García-Benau, M.A.; Sierra, L. Sustainability Development and the Quality of Assurance Reports: Empirical Evidence. Bus. Strat. Environ. 2013, 22, 484-500, doi: org/10.1002/bse.1764.

\section{References}

1. Chiu, T.K.; Wang, Y.H. Determinants of social disclosure quality in Taiwan: An application of stakeholder theory. J. Bus. Ethics 2015, 129, 379-398. [CrossRef]

2. Cormier, D.; Gordon, I.M.; Magnan, M. Corporate environmental disclosure: Contrasting management's perceptions with reality. J. Bus. Ethics 2004, 49, 143-165. [CrossRef]

3. Dong, S.; Burritt, R.; Qian, W. Salient stakeholders in corporate social responsibility reporting by Chinese mining and minerals companies. J. Clean. Prod. 2014, 84, 59-69. [CrossRef]

4. Huang, C.L.; Kung, F.H. Drivers of environmental disclosure and stakeholder expectation: Evidence from Taiwan. J. Bus. Ethics 2010, 96, 435-451. [CrossRef]

5. Lu, Y.; Abeysekera, I. Stakeholders' power, corporate characteristics, and social and environmental disclosure: Evidence from China. J. Clean. Prod. 2014, 64, 426-436. [CrossRef]

6. O'Dwyer, B.; Unerman, J.; Hession, E. User needs in sustainability reporting: Perspectives of stakeholders in Ireland. Eur. Account. Rev. 2005, 14, 759-787. [CrossRef]

7. Rodrigue, M. Contrasting realities: Corporate environmental disclosure and stakeholder-released information. Account. Audit. Account. J. 2014, 27, 119-149. [CrossRef]

8. Thijssens, T.; Bollen, L.; Hassink, H. Secondary stakeholder influence on CSR disclosure: An application of stakeholder salience theory. J. Bus. Ethics 2015, 132, 873-891. [CrossRef]

9. Deegan, C.; Rankin, M.; Tobin, J. An examination of the corporate social and environmental disclosures of BHP from 1983-1997: A test of legitimacy theor. Account. Audit. Account. J. 2002, 15, 312-343. [CrossRef]

10. Hahn, R.; Lülfs, R. Legitimizing negative aspects in GRI-oriented sustainability reporting: A qualitative analysis of corporate disclosure strategies. J. Bus. Ethics 2014, 123, 401-420. [CrossRef]

11. Lai, A.; Melloni, G.; Stacchezzini, R. Corporate sustainable development: Is 'integrated reporting'a legitimation strategy? Bus. Strat. Environ. 2016, 25, 165-177. [CrossRef]

12. Hummel, K.; Schlick, C. The relationship between sustainability performance and sustainability disclosure-Reconciling voluntary disclosure theory and legitimacy theory. J. Account. Public Policy 2016, 35, 455-476. [CrossRef]

13. Chauvey, J.N.; Giordano-Spring, S.; Cho, C.H.; Patten, D.M. The normativity and legitimacy of CSR disclosure: Evidence from France. J. Bus. Ethics 2015, 130, 789-803. [CrossRef]

14. Ali, W.; Frynas, J.G.; Mahmood, Z. Determinants of corporate social responsibility (CSR) disclosure in developed and developing countries: A literature review. Corp. Soc. Responsib. Environ. Manag. 2017, 24, 273-294. [CrossRef]

15. Bebbington, J.; Larrinaga, C.; Moneva, J.M. Corporate social reporting and reputation risk management. Account. Audit. Account. J. 2008, 21, 337-361. [CrossRef]

16. Cho, C.H.; Guidry, R.P.; Hageman, A.M.; Patten, D.M. Do actions speak louder than words? An empirical investigation of corporate environmental reputation. Account. Organ. Soc. 2012, 37, 14-25. [CrossRef]

17. Koch, C.; Schmidt, C. Disclosing conflicts of interest-Do experience and reputation matter? Account. Organ. Soc. 2010, 35, 95-107. [CrossRef]

18. Michelon, G. Sustainability Disclosure and Reputation: A Comparative Study. Corp. Reput. Rev. 2011, 14, 79-96. [CrossRef]

19. Odriozola, M.D.; Baraibar-Diez, E. Is corporate reputation associated with quality of CSR reporting? Evidence from Spain. Corp. Soc. Responsib. Environ. Manag. 2017, 24, 121-132. [CrossRef]

20. Cahan, S.F.; De Villiers, C.; Jeter, D.C.; Naiker, V.; Van Staden, C.J. Are CSR disclosures value relevant? Cross-country evidence. Eur. Account. Rev. 2016, 25, 579-611. [CrossRef]

21. Gallego-Álvarez, I.; Ortas, E. Corporate environmental sustainability reporting in the context of national cultures: A quantile regression approach. I. Bus. Rev. 2017, 26, 337-353. [CrossRef]

22. Garcia-Sanchez, I.M.; Cuadrado-Ballesteros, B.; Frías-Aceituno, J.V. Impact of the institutional macro context on the voluntary disclosure of CSR information. Long Range Plan. 2016, 49, 15-35. [CrossRef] 
23. Llena, F.; Moneva, J.M.; Hernández, B. Environmental disclosures and compulsory accounting standards: The case of Spanish annual reports. Bus. Strat. Environ. J. 2007, 16, 50-63. [CrossRef]

24. Luo, X.R.; Wang, D.; Zhang, J. Whose call to answer: Institutional complexity and firms' CSR reporting. Acad. Manag. J. 2017, 60, 321-344. [CrossRef]

25. Tinker, T.; Neimark, M.; Lehman, C. Falling down the hole in the middle of the road: Political quietism in corporate social reporting. Account. Audit. Account. J. 1991, 4. [CrossRef]

26. Luque-Vílchez, M.; Mesa-Pérez, E.; Husillos, J.; Larrinaga, C. The influence of pro-environmental managers' personal values on environmental disclosure: The mediating role of the environmental organizational structure. Sustain. Account. Manag. Policy J. 2019, in press. [CrossRef]

27. Fassin, Y. The reasons behind non-ethical behaviour in business and entrepreneurship. J. Bus. Ethics 2005, 60, 265-279. [CrossRef]

28. Moneva, J.M.; Llena, F. Análisis de la Información Sobre Responsabilidad Social en las Empresas Industriales Que Cotizan en Bolsa. R. Esp. Financ. Contab. 1996, 25, 361-402.

29. Gray, R.H.; Owen, D.L.; Maunders, K.T. Corporate Social Reporting: Accounting and Accountability; Prentice Hall International: Hemel Hempstead, UK, 1987; ISBN 9780131754645.

30. Van Riel, C.B. Corporate Communication Orchestrated by a Sustainable Corporate Story. In The Expressive Organization; Schultz, M., Hatch, M.J., Larsen, M.H., Eds.; Oxford University Press: Oxford, UK, 2000; pp. 157-181. ISBN 978-0198297796.

31. Cormier, D.; Magnan, M. The Revisited Contribution of Environmental Reporting to Investors' Valuation of a Firm's Earnings: An International Perspective. Ecol. Econ. 2007, 62, 613-626. [CrossRef]

32. Dawkins, C.E.; Fraas, J.W. Coming Clean: The Impact of Environmental Performance and Visibility on Corporate Climate Change Disclosure. J. Bus. Ethics 2011, 100, 303-322. [CrossRef]

33. Drobetz, W.; Merikas, A.; Merika, A.; Tsionas, M.G. Corporate Social Responsibility Disclosure: The Case of International Shipping. Transp. Res. Part. E. 2014, 71, 18-44. [CrossRef]

34. Alexopoulos, I.; Kounetas, K.; Tzelepis, K. Environmental and financial performance. Is there a win or a win-loss situation? Evidence from the Greek manufacturing. J. Clean. Prod. 2018, 197, 1275-1283. [CrossRef]

35. Wittmann, C.M.; Hunt, S.D.; Arnett, D.B. Explaining Alliance Success: Competences, Resources, Relational Factors, and Resource-advantage Theory. Ind. Mark. Manag. 2009, 38, 743-756. [CrossRef]

36. Shleifer, A.; Vishny, R.W. A Survey of Corporate Governance. J. Financ. 1997, 52, 737-783. [CrossRef]

37. Gompers, P.A.; Ishii, J.L.; Metrick, A. Corporate Governance and Equity Prices. Quart. J. Econ. 2003, 118, 107-155. [CrossRef]

38. Giroud, X.; Mueller, H.M. Corporate Governance, Product Market Competition, and Equity Prices. J. Financ. 2011, LXVI(2), 563-600. [CrossRef]

39. Asensio-López, D.; Cabeza-García, L.; González-Álvarez, N. Corporate governance and innovation: A theoretical review. Eur. J. Manag. Bus. Econ. 2018. [CrossRef]

40. Miroshnychenko, I.; Barontini, R.; Testa, F. Corporate governance and environmental performance: A systematic overview. In Ethics, ESG, and Sustainable Prosperity; World Scientific Publishing: Singapore, 2018.

41. Bansal, S.; López-Pérez, M.V.; Rodríguez-Ariza, L. Board Independence and Corporate Social Responsibility Disclosure: The Mediating Role of Presence of Family Ownership. Adm. Sci. 2018, 8, 33. [CrossRef]

42. Ong, T.; Djajadikerta, H.G. Corporate governance and sustainability reporting in the Australian resources industry: An empirical analysis. Soc. Responsib. J. 2018. [CrossRef]

43. Giannarakis, G.; Konteos, G.; Sariannidis, N.; Chaitidis, G. The relation between voluntary carbon disclosure and environmental performance: The case of S\&P 500. Int J. Law Manag. 2017, 59, 784-803. [CrossRef]

44. Ortas, E.; Álvarez, I.; Zubeltzu, E. Firms' Board Independence and Corporate Social Performance: A Meta-Analysis. Sustainability 2017, 9, 1006. [CrossRef]

45. Azutoru, I.H.C.; Obinne, U.G.; Chinelo, O.O. Effect of Corporate Governance Mechanisms on Financial Performance of Insurance Companies in Nigeria. J. Finan. Account. 2017, 5, 93-103. [CrossRef]

46. Albitar, K. Firm characteristics, governance attributes and corporate voluntary disclosure: A study of Jordanian listed companies. Int. Bus. Res. 2015, 8, 1. [CrossRef]

47. Giannarakis, G. Corporate governance and financial characteristic effects on the extent of corporate social responsibility disclosure. Soc. Responsib. J. 2014, 10, 569-590. [CrossRef]

48. Kamal, M.; Saadi, S. Corporate Governance, Economic Turbulence and Financial Performance of UAE Listed Firms. Stud. Econ. Financ. 2013, 30, 118-138. [CrossRef] 
49. Arayssi, M.; Dah, M.; Jizi, M. Women on boards, sustainability reporting and firm performance. Sustain. Account. Manag. Policy J. 2016, 7, 376-401. [CrossRef]

50. Saidat, Z.; Silva, M.; Seaman, C. The relationship between corporate governance and financial performance: Evidence from Jordanian family and nonfamily firms. J. Fam. Bus. Manag. 2018. [CrossRef]

51. Orlitzky, M.; Schmidt, F.L.; Rynes, S.L. Corporate Social and Financial Performance: A Meta-analysis. Organ. Stud. 2003, 24, 403-441. [CrossRef]

52. Allouche, J.; Laroche, P. A Meta-analytical Investigation of the Relationship Between Corporate Social and Financial Performance. Rev. Gest. Resourc. Hum. Eska. 2005, 18, 1-29.

53. Wu, M.L. Corporate Social Performance, Corporate Financial Performance and Firm Size. J. American Acad. Bus. 2006, 8, 163-171.

54. Miras-Rodríguez, M.M.; Carrasco-Gallego, A.; Escobar-Pérez, B. Responsabilidad Social Corporativa y Rendimiento Financiero: Un Meta-análisis. R. Esp. Financ. Contab. 2014, 43, 193-215. [CrossRef]

55. Dang, C.; Li, Z.; Yang, C. Measuring Firm Size in Empirical Corporate Finance. J. Bank. Financ. 2018, 86, 159-176. [CrossRef]

56. Patten, D.M. The Relation Between Environmental Performance and Environmental Disclosure: A Research Note. Account. Organ. Soc. 2002, 27, 763-773. [CrossRef]

57. Al-Tuwaijri, S.A.; Christensen, T.E.; Hughes, K.E. The Relations Among Environmental Disclosures, Environmental Performance, and Economic Performance: A Simultaneous Equations Approach. Account. Organ. Soc. 2004, 29, 447-471. [CrossRef]

58. Amran, A. Corporate Social Reporting in Malaysia: An Institutional Perspective. Unpublished doctoral thesis, University of Malaya, Kuala Lumpur, Malaysia, 2006.

59. Artiach, T.; Lee, D.; Nelson, D.; Walker, J. The Determinants of Corporate Sustainability Performance. Account. Financ. 2010, 50, 31-51. [CrossRef]

60. Haniffa, R.M.; Cooke, T.E. The Impact of Culture and Governance on Corporate Social Reporting. J. Account. Public Policy 2005, 24, 391-430. [CrossRef]

61. Clarkson, P.M.; Li, Y.; Richardson, G.D.; Vasvari, F.P. Revisiting the Relation Between Environmental Performance and Environmental Disclosure: An Empirical Analysis. Account. Organ. Soc. 2008, 33, 303-327. [CrossRef]

62. Clarkson, P.M.; Fang, X.; Li, Y.; Richardson, G. The Relevance of Environmental Disclosures: Are Such Disclosures Incrementally Informative? J. Account. Public Policy 2013, 32, 410-431. [CrossRef]

63. Buhr, N. Histories of and Rationales for Sustainability Reporting. In Sustainability Accounting and Accountability; Unerman, J., Bebbington, J., O’Dwyer, B., Eds.; Routledge: London, UK, 2007; ISBN 0415384885.

64. Cormier, D.; Gordon, I.M. An Examination of Social and Environmental Reporting Strategies. Account. Audit. Account. J. 2001, 14, 587-616. [CrossRef]

65. Ieng, C.; Chatterjee, B.; Brown, A. The Current Status of Greenhouse Gas Reporting by Chinese Companies. A Test of Legitimacy Theory. Manag. Audit. J. 2013, 28, 114-139. [CrossRef]

66. Cho, C.H.; Patten, D.M. The Role of Environmental Disclosures as Tools of Legitimacy: A Research Note. Account. Organ. Soc. 2007, 32, 639-647. [CrossRef]

67. Hughes, S.B.; Anderson, A.; Golden, S. Corporate Environmental Disclosures: Are They Useful in Determining Environmental Performance? J. Account. Public Pol. 2001, 20, 217-240. [CrossRef]

68. Mallin, C.; Farag, H.; Ow-Yong, K. Corporate Social Responsibility and Financial Performance in Islamic Banks. J. Econ. Behav. Organ. 2014, 103, S21-S38. [CrossRef]

69. Leuz, C. Proprietary Versus Non-proprietary Disclosures: Voluntary Cash Flow Statements and Business Segment Reports in Germany; Working Paper; Department of Business and Economics, Johann Wolfgang Goethe-Universitat: Frankfurt, Germany, 1999.

70. Stocken, P.C. Credibility of Voluntary Disclosure. Rand J. Econ. 2000, 31, 359-374. [CrossRef]

71. Skinner, D.J. Earnings Disclosures and Stockholder Lawsuits. J. Account. Econ. 1997, 23, 249-282. [CrossRef]

72. Freedman, M.; Jaggi, B. An Analysis of the Association Between Pollution Disclosure and Economic Performance. Account. Audit. Account. J. 1988, 1, 43-45. [CrossRef]

73. Aupperle, K.; Carroll, A.; Hatfield, J. An Empirical Examination of the Relationship Between Corporate Social Responsibility and Profitability. Acad. Manag. J. 1985, 28, 446-463.

74. Dumontier, P.; Raffournier, B. Why Firms Comply Voluntarily with IAS: An Empirical Analysis with Swiss Data. J. Int. Financ. Manag. Account. 1998, 9, 216-245. [CrossRef] 
75. Meek, G.K.; Roberts, C.B.; Gray, S.J. Factors Influencing Voluntary Annual Report Disclosures by US, UK and Continental European Multinational Corporations. J. Int. Bus. Stud. 1995, 26, 555-572. [CrossRef]

76. McWilliams, A.; Siegel, D. Corporate Social Responsibility and Financial Performance: Correlation or Misspecification? Strat. Manag. J. 2000, 21, 603-609. [CrossRef]

77. Ball, R.; Robin, A.; Wu, J.S. Incentives Versus Standards: Properties of Accounting Income in Four East Asian Countries. J. Account. Econ. 2003, 36, 235-270. [CrossRef]

78. Connelly, J.T.; Limpaphayom, P. Environmental Reporting and Firm Performance: Evidence from Thailand. J. Corp. Citizensh. 2004, 13, 137-149. [CrossRef]

79. Forte, L.M.; Neto, J.B.; Nobre, F.C.; Nobre, L.H.; Queiroz, D.B. Determinants of Voluntary Disclosure: A Study in the Brazilian Baking Sector. Rev. Gest. Financ. Contab. 2015, 5, 23-37. [CrossRef]

80. Pajuelo, M.L. Assessment of the Impact of Business Activity in Sustainability Terms. Empirical Confirmation of Its Determination in Spanish Companies. Sustain. 2013, 5, 2389-2420. [CrossRef]

81. Hull, C.E.; Rothenberg, S. Firm Performance: The Interactions of Corporate Social Performance With the Innovation and Industry Differentiation. Strat. Manag. J. 2008, 29, 781-789. [CrossRef]

82. Surroca, J.; Tribo, J.; Waddock, S. Corporate Responsibility and Financial Performance: The Role of Intangible Resources. Strat. Manag. J. 2010, 31, 463-490. [CrossRef]

83. Van der Laan, G.; Van Ees, H.; Van, A. Corporate Social and Financial Performance: An Extended Stakeholder Theory, and Empirical Test With Accounting Measures. J. Bus. Ethics 2008, 79, 299-310. [CrossRef]

84. Haniffa, R.M.; Cooke, T.E. Culture, Corporate Governance and Disclosure in Malaysian Corporations. Abacus 2002, 38, 317-349. [CrossRef]

85. AbdRahman, N.H.W.; Zain, M.M.; YaakopYahaya Al-Haj, N.H. CSR Disclosure and Its Determinants: Evidence from Malaysian Government Link Companies. Soc. Responsib. J. 2011, 7, 181-201. [CrossRef]

86. Ho, S.S.M.; Wong, K.S. A Study of the Relationship Between Corporate Governance Structures and the Extent of Voluntary Disclosure. J. Int. Account. Audit. Tax. 2001, 10, 139-156. [CrossRef]

87. Hamrouni, A.; Miloudi, A.; Benkraiem, R. Signaling Firm Performance Through Corporate Voluntary Disclosure. J. Appl. Bus. Res. 2015, 31, 609-620. [CrossRef]

88. Francis, J.; Nanda, D.; Olsson, P. Voluntary Disclosure, Earnings Quality, and Cost of Capital. J. Account. Res. 2008, 46, 53-99. [CrossRef]

89. Dragomir, V.D. Environmentally Sensitive Disclosures and Financial Performance in a European Setting. J. Account. Organ. Change. 2010, 6, 359-388. [CrossRef]

90. Gao, L.S.; Connors, E. Corporate Environmental Performance, Disclosure and Leverage: An Integrated Approach. Accounting and Finance Faculty Publications Series Paper 6; Scholar Works: Boston, MA, USA, 2011.

91. Cochran, P.L.; Wood, R.A. Corporate Social Responsibility and Financial Performance. Acad. Manag. J. 1984, 27, 42-56. [CrossRef]

92. Freedman, M.; Jaggi, B. Pollution Disclosures, Pollution Performance and Economic Performance. OMEGA, Int. J. Manag. Sci. 1982, 10, 167-176. [CrossRef]

93. Hasseldine, J.; Salama, A.I.; Toms, J.S. Quantity Versus Quality: The Impact of Environmental Disclosures on the Reputations of UK PLCs. Brit. Account. Rev. 2005, 37, 231-248. [CrossRef]

94. Guidry, R.P.; Patten, D.M. Voluntary Disclosure Theory and Financial Control Variables: An Assessment of Recent Environmental Disclosure Research. Account. Forum 2012, 36, 81-90. [CrossRef]

95. Dawkins, C.E.; Fraas, J.W. Erratum to Beyond Acclamations and Excuses: Environmental Performance, Voluntary Environmental Disclosure and the Role of Visibility. J. Bus. Ethics 99, 383-397. [CrossRef]

96. Delmas, M.; Blass, V.D. Measuring Corporate Environmental Performance: The Trade-Offs of Sustainability Ratings. Bus. Strat. Environ. 2010, 19, 245-260. [CrossRef]

97. Salem, N.; Kavanagh, M.; Slaughter, G. An Empirical Study of the Relationship Between Corporate Social Responsibility Disclosure and Organizational Performance: Evidence from Libya. Int. J. Manag. Mark. Res. 2012, 5, 69-82.

98. Contrafatto, M. The Institutionalization of Social and Environmental Reporting: An Italian Narrative. Account. Organ. Soc. 2014, 39, 414-432. [CrossRef]

99. Adams, C. Internal Organizational Factors Influencing Corporate Social and Ethical Reporting: Beyond Current Theorizing. Account. Audit. Account. J. 2002, 15, 223-250. [CrossRef]

100. Contrafatto, M. Il Social Environmental Reporting eleSue Motivazioni: Teoria, AnalisiEmpirica e Prospecttive; Guiffré: Milan, Italy, 2009; ISBN 978-8814144769. 
101. Adams, C.; McNicholas, P. Making a Difference: Sustainability Reporting, Accountability and Organizational Change. Account. Audit. Account. J. 2007, 20, 382-402. [CrossRef]

102. Line, M.; Hawley, H.; Krut, R. The Development of Global Environmental and Social Reporting. Corp. Environ. Strat. 2002, 9, 69-78. [CrossRef]

103. Gray, R.; Javad, M.; Porter, D.M.; Sinclair, C.D. Social and Environmental Disclosure and Corporate Characteristics: A Research Note and Extension. J. Bus. Fin. Account. 2001, 28, 327-356. [CrossRef]

104. Hossain, M.; Hammami, H. Voluntary Disclosure in the Annual Reports of an Emerging Country: The Case of Qatar. Adv. Account. 2009, 25, 255-265. [CrossRef]

105. James-Overheu, C.; Cotter, J. Corporate Governance, Sustainability and the Assessment of Default Risk. Asian J. Financ. Account. 2010, 1, 34-53. [CrossRef]

106. Kansal, M.; Joshi, M.; Batra, G.S. Determinants of Corporate Social Responsibility Disclosures: Evidence from India. Adv. Account. 2014, 30, 217-229. [CrossRef]

107. Ionel-Alin, I. Analyze of Environmental Disclosure Within European Union Countries. J. Knowl. Manag. Econ. Inf. Technol. 2012, 4, 1-23.

108. Campbell, D. Intra and Intersectoral Effects in Environmental Disclosures: Evidence for Legitimacy Theory? Bus. Strat. Environ. J. 2003, 42, 207-252. [CrossRef]

109. Deegan, C.; Gordon, B. A Study of Environmental Disclosure Practices of Australian Corporations. Account. Bus. Res. 1996, 26, 187-199. [CrossRef]

110. Fernandez-Feijoo, B.; Romero, S.; Ruiz, S. Commitment to Corporate Social Responsibility Measured Through Global Reporting Initiative Reporting: Factors Affecting the Behaviour of Companies. J. Clean. Prod. 2014, 81, 244-254. [CrossRef]

111. Patten, D.M. Exposure, Legitimacy and Social Disclosure. J. Account. Public Policy 1991, 10, $297-308$. [CrossRef]

112. Roberts, R.W. Determinants of Corporate Social Disclosure: An Application of Stakeholder Theory. Account. Organ. Soc. 1992, 17, 595-612. [CrossRef]

113. Luethge, D.; Guohong Han, H. Assessing Corporate Social and Financial Performance in China. Soc. Responsib. J. 2012, 8, 389-403. [CrossRef]

114. Magness, V. Strategic Posture, Financial Performance and Environmental Disclosure. An Empirical Test of Legitimacy Theory. Account. Audit. Account. 2006, 19, 540-563. [CrossRef]

115. Menassa, E. Corporate Social Responsibility. An Exploratory Study of the Quality and Extent of Social Disclosures by Lebanese Commercial Banks. J. Appl. Account. Res. 2010, 11, 4-23. [CrossRef]

116. Miras-Rodríguez, M.M.; Carrasco-Gallego, A.; Escobar-Pérez, B. Are Socially Responsible Behaviors Paid Off Equally? A Cross-cultural Analysis. Corp. Soc. Responsib. Environ. Manag. 2015, 22, 237-256. [CrossRef]

117. Fernández, J.L.; Luna, L. The Creation of Value Through Corporate Reputation. J. Bus. Ethics 2007, 76, 335-346. [CrossRef]

118. Singh, J.; de los Salmones Sanchez, M.M.G.; Del Bosque, I.R. Understanding Corporate Social Responsibility and Product Perceptions in Consumer Markets: A Cross-cultural Evaluation. J. Bus. Ethics 2008, 80, 597-611. [CrossRef]

119. Svensson, G.; Wood, G.; Singh, J.; Carasco, E.; Callaghan, M. Ethical Structures and Processes of Corporations Operating in Australia, Canada, and Sweden: A Longitudinal and Cross-cultural Study. J. Bus. Ethics 2009, 86, 485-506. [CrossRef]

120. Kolk, A. Sustainability, Accountability andCorporate Governance: Exploring Multinationals' Reporting Practices. Bus. Strat. Environ. J. 2008, 17, 1-15. [CrossRef]

121. Hartman, L.; Rubin, R.; Dhanda, K. Communications and Corporate Social Responsibility: United States and European Union Multinational Corporations. J. Bus. Ethics 2007, 74, 373-389. [CrossRef]

122. Van der Laan Smith, J.; Adhikari, A.; Tondkar, R.H. Exploring Differences in Social Disclosures Internationally: A Stakeholder Perspective. J. Account. Public Policy 2005, 24, 123-151. [CrossRef]

123. Kolk, A.; Perego, P. Determinants of the Adoption of Sustainability Assurance Statements: An International Investigation. Bus. Strat. Environ. J. 2010, 19, 182-198. [CrossRef]

124. Adelopo, I. Voluntary Disclosure Practices Amongst Listed Companies in Nigeria. Adv. Account. 2011, 27, 338-345. [CrossRef]

125. Siregar, S.V.; Bachtiar, Y. Corporate Social Reporting: Empirical Evidence From Indonesia Stock Exchange. Int. J. Islamic Middle East. Financ. Manag. 2010, 3, 241-252. [CrossRef] 
126. Hope, O.K. Firm-level disclosures and the relative roles of culture and legal origin. J. Int. Financ. Manag. Account. 2003, 14, 218-248. [CrossRef]

127. Vurro, C.; Perrini, F. Making the Most of Corporate Social Responsibility Reporting: Disclosure Structure and Its Impact on Performance. Corp. Gov. 2011, 11, 459-474. [CrossRef]

128. Al-Ajmi, M.; Al-Mutairi, A.; Al-Duwaila, N. Corporate Social Disclosure Practices in Kuwait. Int. J. Econ. Financ. 2015, 7, 244-254. [CrossRef]

129. Bens, D.A.; Monahan, S.J. Disclosure Quality and the Excess Value of Diversification. J. Account. Res. 2004, 42, 691-730. [CrossRef]

130. Chan, M.C.; Watson, J.; Woodliff, D. Corporate Governance Quality and CSR Disclosures. J. Bus. Ethics 2014, 125, 59-73. [CrossRef]

131. Castelo Branco, M.; Lima Rodriguez, L. Factors Influencing Social Responsibility Disclosure by Portuguese Companies. J. Bus. Ethics 2008, 83, 685-701. [CrossRef]

132. Cho, C.H.; Freedman, M.; Patten, D.M. Corporate Disclosure of Environmental Capital Expenditures. A Test of Alternative Theories. Account. Audit. Account. J. 2012, 25, 486-507. [CrossRef]

133. Sánchez-Meca, J. Meta-análisis Para la Investigación Científica. In Metodología Para la Investigación en Marketing y Dirección de Empresas; Sarabia-Sánchez, F.J., Ed.; Pirámide: Madrid, Spain, 1999; pp. 173-201. ISBN 9788436813425.

134. Eisend, M. Morality effects and consumer responses to counterfeit and pirated products: A meta-analysis. J. Bus. Ethics 2019, 154, 301-323. [CrossRef]

135. Ismagilova, E.; Slade, E.; Rana, N.P.; Dwivedi, Y.K. The effect of characteristics of source credibility on consumer behaviour: A meta-analysis. J. Retail. Consum. Serv 2019, in press. [CrossRef]

136. Zhang, Y.; Weng, Q.; Zhu, N. The relationships between electronic banking adoption and its antecedents: A meta-analytic study of the role of national culture. Int. J. Inf. Manag. 2018, 40, 76-87. [CrossRef]

137. Guerrero-Villegas, J.; Pérez-Calero, L.; Hurtado-González, J.; Giráldez-Puig, P. Board Attributes and Corporate Social Responsibility Disclosure: A Meta-Analysis. Sustainability 2018, 10, 4808. [CrossRef]

138. Hamari, J.; Keronen, L. Why do people play games? A meta-analysis. Int. J. Inf. Manag. 2017, 37, $125-141$. [CrossRef]

139. Geyskens, I.; Krishnan, R.; Steenkamp, J.B.E.; Cunha, P.V. A Review and Evaluation of Meta-analysis Practices in Management Research. J. Manag. 2009, 35, 393-419. [CrossRef]

140. Hunter, J.E.; Schmidt, F.L. Meta-analysis: Correcting Error and Bias in Research Findings, 2nd ed.; Sage: Thousand Oaks, CA, USA, 2004; ISBN 1452286892.

141. Hawcroft, J.L.; Milfont, L.T. The Use (and Abuse) of the New Environmental Paradigm Scale Over the Last 30 Years: A Meta-analysis. J. Environ. Psychol. 2010, 30, 143-158. [CrossRef]

142. Marcus, B.; Taylor, O.A.; Hastings, S.E.; Sturm, A.; Weigelt, O. The Structure of Counterproductive Work Behavior. A Review, a Structural Meta-analysis, and a Primary Study. J. Manag. 2013, 42, 203-233. [CrossRef]

143. Sánchez-Meca, J. Meta-análisis de la Investigación. In Metodología en la Investigación Sobre Discapacidad. Introducción al Uso de las Ecuaciones Estructurales; Verdugo Manuela Crespo, M.Á., Badía, M., Arias, B., Eds.; VI Seminario Científico SAID, Publicaciones del INICO, Colección Actas: Salamanca, Spain, 2008; pp. 121-140.

144. Sánchez-Meca, J.; Marín-Martínez, F.; López-López, J.A. Metodología del Meta-análisis. In Métodos de Investigación Social y de la Empresa; Sarabia Sánchez, F., Ed.; Pirámide: Madrid, Spain, 2013; pp. 447-470.

145. Wallace, J.C.; Edwards, B.D.; Paul, J.; Burke, M.; Christian, M.S.; Eissa, G. Change the Referent? A Meta-analytic Investigation of Direct and Referent-shift Consensus Models for Organizational Climate. J. Manag. 2016, 42, 838-861. [CrossRef]

146. Moher, D.; Liberati, A.; Tetzlaff, J.; Altman, D.G. The PRISMA Group. Preferred Reporting Items for Systematic Reviews and Meta-Analyses: The PRISMA Statement. PLoS Med. 2009, 6, e1000097. [CrossRef]

147. David, R.J.; Han, S.K. A Systematic Assessment of the Empirical Support for Transaction Cost Economics. Strat. Manag. J. 2004, 25, 39-58. [CrossRef]

148. Newbert, S.L. Empirical Research on the Resource-based View of the Firm: An Assessment and Suggestions for Future Research. Strat. Manag. J. 2007, 28, 121-146. [CrossRef]

149. Palmatier, R.W.; Dant, R.; Grewal, D.; Evans, K. Factors Influencing the Effectiveness of Relationship Marketing: A Meta-analysis. J. Mark. 2006, 70, 136-153. [CrossRef] 
150. Hunter, J.E.; Schmidt, F.L. Methods of Meta-analysis: Correcting Error and Bias in Research Findings; Sage: Newbury Park, CA, USA, 1990; ISBN 141290479X.

151. Barroso-Mendez, M.J.; Galera-Casquet, C.; Valero-Amaro, V. Proposal of a Social Alliance Success Model from a Relationship Marketing Perspective: A Meta-analytical Study of the Theoretical Foundations. Bus. Res. Quart. 2015, 18, 188-203. [CrossRef]

152. Peterson, R.A.; Brown, S.P. On the Use of Beta Coefficients in Meta-analysis. J. Appl. Psychol. 2005, 90, 175-181. [CrossRef]

153. Rothstein, H.R.; Sutton, A.J.; Borenstein, M. (Eds.) Publication Bias in Meta-analysis: Prevention, Assessment, and Adjustments; Wiley: Chichester, UK, 2005; ISBN 978-0470870143.

154. Cohen, J. Statistical Power Analysis for the Behavioral Sciences, 2nd ed.; Erlbaum: Hillsdale, NJ, USA, 1988; ISBN 9780805802832.

155. Margolis, J.D.; Elfenbein, H.A.; Walsh, J.P. Does It Pay to Be Good? A Meta-analysis and Redirection of Research on the Relationship Between Corporate Social and Financial Performance; Working Paper; Ross School of Business, University of Michigan: Ann Arbor, MI, USA, 2007.

156. Waldman, D.A.; de Luque, M.S.; Washburn, N.; House, R.J. Cultural and Leadership Predictors of Corporate Social Responsibility Values of Top Management: A GLOBE Study of 15 Countries. J. Int. Bus. Stud. 2006, 37, 823-837. [CrossRef]

157. Rosenthal, R.; Di Matteo, M.R. Meta-analysis: Recent Developments in Quantitative Methods for Literature Reviews. Annu. Rev. Psychol. 2001, 52, 59-82. [CrossRef] [PubMed]

158. Li, F. Endogeneity in CEO Power: A Survey and Experiment. Invest. Anal. J. 2016, 45, 149-162. [CrossRef]

(C) 2019 by the authors. Licensee MDPI, Basel, Switzerland. This article is an open access article distributed under the terms and conditions of the Creative Commons Attribution (CC BY) license (http:/ / creativecommons.org/licenses/by/4.0/). 